\title{
Label-free quantitative proteomics of Sorghum bicolor reveals the proteins strengthening plant defense against insect pest Chilo partellus
}

Vaijayanti A. Tamhane ${ }^{1 *}$ (D) Surhud S. Sant ${ }^{1,2+}$, Abhilash R. Jadhav ${ }^{1+}$, Abdul R. War ${ }^{3,4}$, Hari C. Sharma ${ }^{3,5}$, Abdul Jaleel ${ }^{6}$ and Akanksha S. Kashikar ${ }^{7}$

\begin{abstract}
Background: Spotted stem borer- Chilo partellus - a Lepidopteran insect pest of Sorghum bicolor is responsible for major economic losses. It is an oligophagous pest, which bores through the plant stem, causing 'deadheart' and hampering the development of the main cob. We applied a label-free quantitative proteomics approach on three genotypes of S. bicolor with differential resistance/ susceptibility to insect pests, intending to identify the S. bicolor's systemic protein complement contributing to C. partellus tolerance.

Methods: The proteomes of S. bicolor with variable resistance to insect pests, ICSV700, IS2205 (resistant) and Swarna (susceptible) were investigated and compared using label-free quantitative proteomics to identify putative leaf proteins contributing to resistance to C. partellus.

Results: The multivariate analysis on a total of 967 proteins led to the identification of proteins correlating with insect resistance/susceptibility of S. bicolor. Upon C. partellus infestation S. bicolor responded by suppression of protein and amino acid biosynthesis, and induction of proteins involved in maintaining photosynthesis and responding to stresses. The gene ontology analysis revealed that $C$. partellus-responsive proteins in resistant $S$. bicolor genotypes were mainly involved in stress and defense, small molecule biosynthesis, amino acid metabolism, catalytic and translation regulation activities. At steady-state, the resistant S. bicolor genotypes displayed at least two-fold higher numbers of unique proteins than the susceptible genotype Swarna, mostly involved in catalytic activities. Gene expression analysis of selected candidates was performed on S. bicolor by artificial induction to mimic C. partellus infestation.
\end{abstract}

Conclusion: The collection of identified proteins differentially expressed in resistant S. bicolor, are interesting candidates for further elucidation of their role in defense against insect pests.

Keywords: Chilo partellus, Insect pests, in-solution proteomics, Plant defense, Label-free quantitative proteomics

\footnotetext{
*Correspondence: vatamhane@unipune.ac.in; vatamhane@gmail.com

†'Surhud S. Sant and Abhilash R. Jadhav contributed equally to this work. ${ }^{1}$ Institute of Bioinformatics and Biotechnology (IBB), Savitribai Phule Pune University (SPPU), Ganeshkhind Road, Pune, Maharashtra 411 007, India

Full list of author information is available at the end of the article
}

(c) The Author(s). 2021 Open Access This article is licensed under a Creative Commons Attribution 4.0 International License, which permits use, sharing, adaptation, distribution and reproduction in any medium or format, as long as you give appropriate credit to the original author(s) and the source, provide a link to the Creative Commons licence, and indicate if changes were made. The images or other third party material in this article are included in the article's Creative Commons licence, unless indicated otherwise in a credit line to the material. If material is not included in the article's Creative Commons licence and your intended use is not permitted by statutory regulation or exceeds the permitted use, you will need to obtain permission directly from the copyright holder. To view a copy of this licence, visit http://creativecommons.org/licenses/by/4.0/ The Creative Commons Public Domain Dedication waiver (http://creativecommons.org/publicdomain/zero/1.0/) applies to the data made available in this article, unless otherwise stated in a credit line to the data. 


\section{Background}

S. bicolor (L.) Moench is an important food, forage and biofuel Saccharinae crop cultivated world over, and recognized for its high yield and stress tolerance. It is the fifth most important cereal crop in the world after rice, wheat, maize and barley and it is the third important cereal crop after rice and wheat in India [1]. The molecular, biochemical and biotechnological investigations in S. bicolor are vital for its sustainable supply and it has been recognized as a model plant system for stress proteomics and genomics research [2,3]. Over 150 insect species are known to cause damage to S. bicolor crops, of which, shoot fly (Atherigona soccata), spotted stem borer (Chilo partellus), midge (Contarinia sorghicola) and head bugs (Calocoris angustatus, Eurtystylus spp.) are the major pests. The lepidopteran insect pest C. partellus is an oligophagous pest, which feeds on cereals like maize, $S$. bicolor, or other wild grasses and is predominant in the warmer regions of the tropics [4]. Of the 58 species in the Chilo genus, C. partellus is recognized as a major pest causing estimated global losses of over $\$ 300$ million annually [5, 6]. C. partellus neonates feed on tender leaves, causing leaf-scarification, shot-holes and later bore into the stem, causing deadheart [7], destruction of the meristem, and disruption of flowering/ seed set $[8,9]$.

Crop plants have lost the evolutionarily acquired defense mechanisms, due to domestication and repeated selections for agronomic traits [10]; while insects have expanded their geographical horizons to emerge as pests [11]. In $S$. bicolor breeding programs, studies have emphasized the importance of wild germplasm and host plant resistance as a source of insect defense traits for selection breeding $[12,13]$. 'Omics' approaches have accelerated the elucidation of regulatory processes, novel molecular mechanisms and adaptations in plant-insect interactions, the findings from which have great potential to steer biotic and abiotic stress tolerance in crop plants [14]. Proteome regulates plant phenotype, its responses to stresses and is intricately linked to its transcriptome and metabolome [15]. Proteomics, with the advances in mass spectrometry, has the promise to provide a snapshot into the molecular and functional networks operating within plants and displays a 'plant molecular phenotype' [16].

Proteomic studies in S. bicolor are swiftly increasing and are focused mainly on osmotic stress [17], grain development and nutritional quality [18], seed storage protein kafirin accumulation [19], salt tolerance [20], heavy metal tolerance $[21,22]$, albino mutant [23, 24] and drought tolerance $[25,26]$. However, the global proteome analysis of $S$. bicolor insect-resistant genotypes and the genetic, biochemical and molecular mechanisms involved in plant defense against pests is not well elucidated. S. bicolor like many cereal crops is heavily sprayed with pesticides during its growth to maintain yields /grain quality [27]. Insights from plant-insect interaction studies will be valuable to envisage and employ the much desired sustainable and environmentally gracious cultivation of $S$. bicolor. S. bicolor is known to induce cyanogenic glucoside- dhurrin, toxic cyanides and other secondary metabolites such as triterpenols upon insect infestation [28]. Genes like NBS LRR and disease resistance phloem protein 2 were identified as contributors of defense against the sugarcane aphid $\mathrm{Mel}$ anaphis sacchari [29], however, omics and molecular studies on lepidopteran pests of $S$. bicolor are scarce.

$S$. bicolor- lepidopteran insect pest interaction proteomics has been attempted in this study to identify the proteins contributing to insect defense in three sorghum genotypes with varied susceptibility to the spotted stem borer infestation. S. bicolor genotypes ICSV700 and IS2205 are known to have variable degree of resistance to $C$. partellus respectively $[1,30]$ while the cultivated variety (Swarna) is susceptible. The genotypes were evaluated for insect resistance based on percentage of a 'deadheart' formation, the extent of leaf damage, stem tunneling, panicle damage and recovery [30].

The proteomics of leaves of S. bicolor genotypes at steady-state and upon infestation by the stem borer $C$. partellus has been performed with an objective to (i) elucidate the important proteins contributing to S. bicolor insect resistance/susceptibility (ii) proteome complement specific to $S$. bicolor genotype and $C$. partellus treatment. Thorough multivariate statistical analyses for simultaneous comparisons across more than two groups were performed on the proteomics data using the opensource statistical software R. The identified proteins need to be evaluated for potential to enhance plant defense against insect pests and will be useful to engineer these traits to improve sustainable insect tolerance in S. bicolor.

\section{Materials and methods \\ Plant material and treatments}

Three S. bicolor genotypes, two resistant (ICSV700, IS2205) and one cultivated, susceptible (Swarna) to infestation by insect pest $C$. partellus were grown in the fields at the International Crop Research Institute for the Semi-Arid Tropics (ICRISAT), Patancheru, India (Table 1). Plants were grown in a randomized complete block design (RBD) (Fig. 1) containing 4-row plots of $2 \mathrm{~m}$ length, with ridges $75 \mathrm{~cm}$ apart. The seedlings were thinned and the planting was maintained at 20 seedlings per $2 \mathrm{~m}$ row. The infestation with $C$. partellus was carried out in fields 18 days after germination with the help of the Bazooka applicator [5]. Un-infested rows were maintained as a control. Young leaves (5-8 g) 


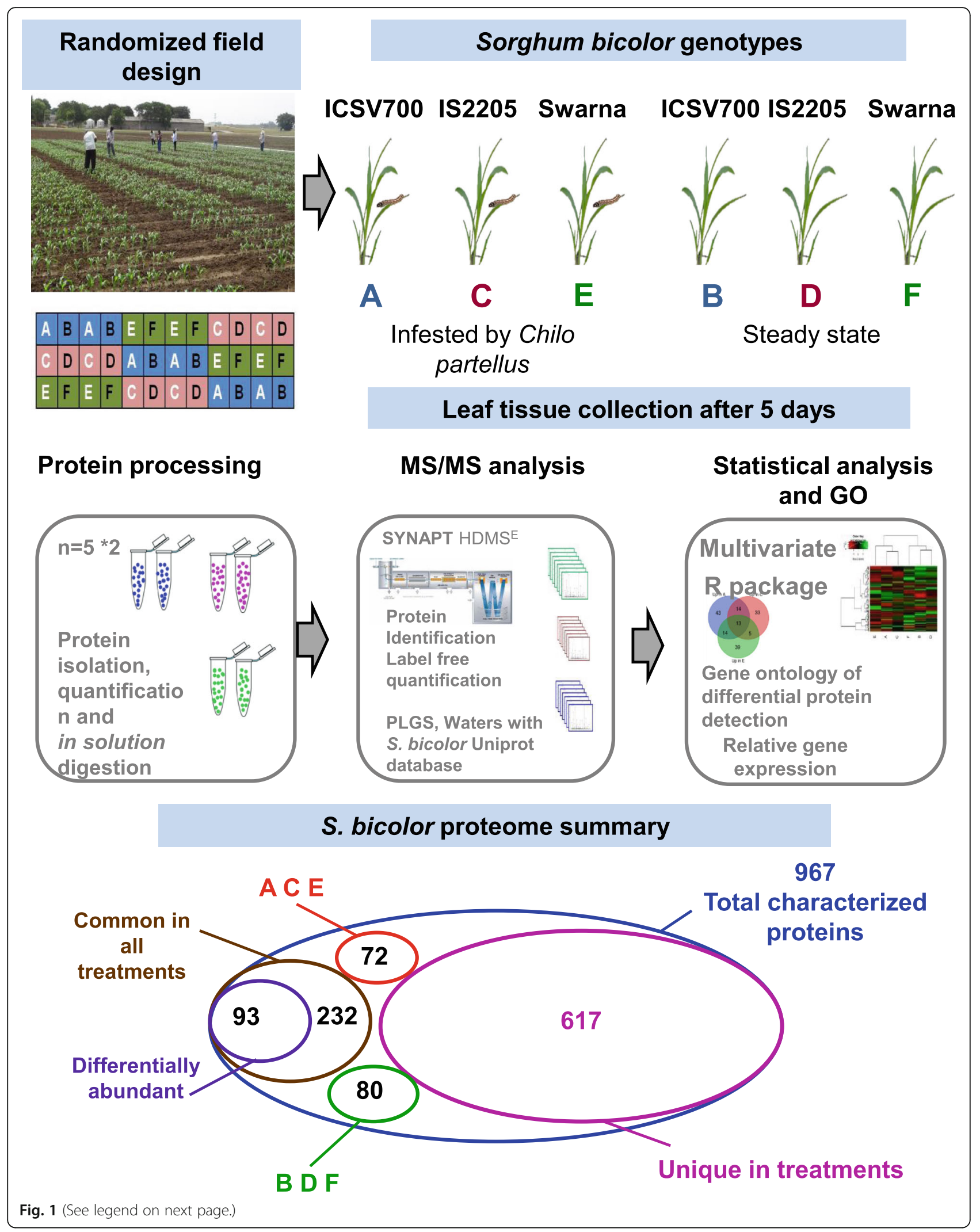


(See figure on previous page.)

Fig. 1 Experimental overview| Three S. bicolor genotypes (ICSV700, IS2205, Swarna) with varied insect-susceptibility were planted in the field in randomized block design. Insect-infestation was carried out with the Bazooka applicator and leaves were collected 5 days post-infestation. Leaves from 5 plants were pooled and considered as a biological replicate, and two such replicates were used in the analysis. The proteins were isolated from leaves and subjected to in-solution digestion. The MS-MS analysis was performed with SYNAPT HDMS ${ }^{\mathrm{E}}$ and S. bicolor proteome was used for protein identification. Proteins were analyzed using non-parametric multivariate tests using R. Further, gene ontology and gene expression

analysis of proteins were performed

from insect-infested and the un-infested (control) plants were collected 5 days post infestation and flash-frozen in liquid nitrogen. It has been reported that plants signal defense against insect pests at a local level, in plant tissue damaged by the insect as well as at the systemic level, in an undamaged part of the plant [31-33]. Leaves represent a systemic tissue of $C$. partellus infested $S$. bicolor plants as the actual feeding by insect happens at the leaf bases and in the stem. Leaves collected from five plants were pooled and considered as a biological replicate, and two such replicates were collected per treatment. This was done for all the three $S$. bicolor genotypes with $C$. partellus infestation (A, C, E) and control (steady-state) (B, D, F) treatments as abbreviated and detailed in Table 2.

\section{Insect rearing and artificial infestation}

C. partellus larvae were obtained from the insect rearing laboratory at the ICRISAT, Patancheru, India. The insects were reared on S. bicolor-based semi-synthetic artificial diet under controlled conditions $(16: 8 \mathrm{~h} \mathrm{~L}: \mathrm{D}$ at $25 \pm 1{ }^{\circ} \mathrm{C}$ and $\left.65 \pm 5 \% \mathrm{RH}\right)$ as reported [5]. Newly emerged larvae were mixed with poppy seeds and released onto the leaf whorls of 18-20 days old plants by the Bazooka applicator [5]. About 10 larvae were released on each plant using two strokes of the Bazooka.

\section{Protein extraction, LC-MS/MS and data analysis}

Total protein extraction was done using a phenol extraction method as described earlier [34]. In short, S. bicolor leaf tissues stored at $-80^{\circ} \mathrm{C}$ were ground to a fine powder in liquid nitrogen with mortar and pestle. The total proteins were extracted from the frozen leaf powder ( $1.5 \mathrm{~g})$ using the phenol extraction method and they were quantified with Bradford assay [35] using Bovine serum albumin (BSA) as a standard. Protein quality was checked by resolving proteins on $12 \%$ SDS-PAGE. Proteins were reconstituted to a final concentration of $1 \mu \mathrm{g} /$ $\mu \mathrm{L}$ with $0.1 \%$ Rapigest $^{\mathrm{mm}}$ in $50 \mathrm{mM}$ ammonium bicarbonate. One hundred microgram of protein from each sample $(1 \mu \mathrm{g} / \mu \mathrm{L})$ was used for in-solution reduction and alkylation followed by trypsin digestion to obtain the peptides [34].

Peptide samples were analyzed using a nano ACQUITY UPLC chromatographic system (Waters, Manchester, UK) where each sample was run thrice to obtain three technical replicates corresponding to each biological replicate (Table 1). The instrument was operated and controlled by MassLynx4.1 SCN781 software. The peptide resolution conditions were as detailed by Sharan et al [34]. SYNAPT ${ }^{\circ}$ G2 High Definition MS $^{\text {tm }}$ System (HDMS ${ }^{\mathrm{E}}$ System) (Waters Corporation, Milford, USA) was used to carry out mass spectrometry analysis of eluting peptides with instrument settings as; nano-ESI capillary voltage $-3.4 \mathrm{kV}$, sample cone $-40 \mathrm{~V}$, extraction cone - $4 \mathrm{~V}$, IMS gas $\left(\mathrm{N}_{2}\right)$ flow $-90(\mathrm{ml} / \mathrm{min})$. All analyses were performed using positive mode ESI using a NanoLockSpray $^{\text {ma }}$ source as detailed in [34]. Protein identification and label-free relative protein quantification were done by analyzing LC-MS/MS data using ProteinLynx Global Server $^{\mathrm{rm}}$ v2.5.3 (PLGS, Waters Corporation) for each technical replicate. Noise reduction thresholds for low energy scan ion, high-energy scan ion, and peptide intensity were set at 150, 50 and 500 counts, respectively as suggested by the manufacturer. A peptide was required to have at least two assigned fragments, and a protein was required to have at least 2 assigned peptides and 3 assigned fragments for identification. S. bicolor database downloaded from the UniProt database (http:// www.uniprot.org/proteomes/UP000000768; the number of sequences 41,380 ) was searched for protein identification and the protein false positive rate was set to $4 \%$. A ratio of $>1.5$ represented over-represented proteins and $<0.65$ represents under-represented proteins (Fig. 3, Supplementary Data 1). The number of proteins identified in each of the biological and technical replicates of the $S$. bicolor genotypes is reported in Table 1 .

\section{In house statistical analysis of the proteomics data}

Proteomics data from the S. bicolor genotypes at steady state and upon in field C. partellus infestation (consisting of two biological replicates per treatment with three technical replicates each) was analyzed using multiple non-parametric statistical tests. The pipeline used for analysis was developed in-house using R (https://www.Rproject.org/) for comparing multiple treatments simultaneously. Considering the biological and technical runs samples (A-F) was represented by six replicates each. Proteins found in at least two technical replicates were considered as truly present and were used for further analysis. The protein data along with the intensity values were $\log$-transformed with base 2 and median 
Table 1 Characteristics of S. bicolor genotypes used in the proteomics study

\begin{tabular}{|c|c|c|c|}
\hline \multirow[t]{2}{*}{ Characteristics } & \multicolumn{3}{|l|}{ S. bicolor genotypes } \\
\hline & ICSV700 & IS2205 & Swarna \\
\hline Panicle & $\begin{array}{l}\text { Fully exerted, compact, elliptic and presence } \\
\text { of awns. }\end{array}$ & $\begin{array}{l}\text { Semi-compact and elliptic. } \\
\text { Panicle weight of } 53 \mathrm{~g} \text {. }\end{array}$ & $\begin{array}{l}\text { Fully exerted, loose, erect and absence } \\
\text { of awns. }\end{array}$ \\
\hline Flowering & $\begin{array}{l}\text { It takes } 80-85 \text { days to flower and matures } \\
\text { in } 120-125 \text { days. }\end{array}$ & $\begin{array}{l}\text { Takes about } 80 \text { days to flowering, } \\
\text { and matures in about } 90-100 \\
\text { days. }\end{array}$ & Flowering takes place after 65 days. \\
\hline Grains & $\begin{array}{l}\text { Lustrous, small-sized grains and } 55 \% \text { grain } \\
\text { covered with glumes. } 100 \text { seeds weigh } \\
\text { around } 2.3 \mathrm{~g} \text {. }\end{array}$ & $\begin{array}{l}\text { White, lustrous. } 100 \text { seed weight } \\
\text { of } 2.6 \mathrm{~g} \text {. }\end{array}$ & $\begin{array}{l}\text { Lustrous and around } 25 \% \text { grains are covered } \\
\text { with glumes. Mass of } 100 \text { seeds is around } 3.5 \mathrm{~g} \text {. }\end{array}$ \\
\hline Plant height & $250 \mathrm{~cm}$ & $250 \mathrm{~cm}$ & up to $166 \mathrm{~cm}$ \\
\hline $\begin{array}{l}\text { Insect Resistant/ } \\
\text { Susceptible }\end{array}$ & Moderately Resistant & Resistant & Susceptible \\
\hline
\end{tabular}

Morphological, growth, seed features and Chilo partellus susceptibility of the three S. bicolor genotypes used [30]

normalization was carried out to remove the effect of outliers. Kruskal-Wallis test (for multiple groups) was used instead of ANOVA to compare the results among the samples as it is more robust, can handle an unequal number of observations and non-parametric method that works better for small sample sizes. The $p$-values were adjusted to control the false discovery rate at $5 \%$. Multivariate statistical techniques viz. Cluster Analysis, Principal Component Analysis (PCA) and Orthogonal Partial Least Squares Discriminant Analysis (OPLS-DA) were used to study the similarities and differences among protein expression patterns from different samples (Fig. 2). An average of all technical and biological replicates was used to avoid the problem of missing values during cluster analysis. As a result, for each protein, we had only six readings, one corresponding to each treatment.

In PCA, proteins identified from each technical replicate were used independently. The missing values were replaced by zeros. Proteins showing significantly different abundance from both ends of the S-plot were identified (in all 68 proteins) and studied separately to examine their behavior in each of the six groups (Table 3 ). The proteins commonly found in all treatments were subjected to pair-wise comparisons using the Mann-Whitney test (a non-parametric equivalent of the t-test, which can handle an unequal number of observations), to identify the proteins which were differentially expressed in either susceptible/resistant or induced/un-induced samples. Proteins not commonly found across samples (A-F) were further studied in the following ways (i) proteins uniquely present in an individual sample, (ii) proteins common in C. partellus induced S. bicolor were studied as ACE comparison group and (iii) proteins common in the steady-state samples were studied as (iii) BDF comparison group represented in (Fig. 4). In the case of the infested group (ACE) and un-infested group (BDF), averaged out log-transformed data for each protein from all technical replicates was used to generate a normalized (across comparison groups) heat map using $\mathrm{MeV}$ 4.9.0 Multiple Experiment Viewer [36].

\section{GO classification, pathway enrichment analysis}

The functional classification of identified proteins was carried out using the UniProt database [37]. Further, gene ontology (GO) analysis of identified differentially expressed proteins was carried out using the PANT HER tool [38]. Common proteins, unique proteins, proteins from infested and un-infested samples were analyzed for molecular function, biological process and cellular component using accession number as an ID and S. bicolor as an organism in the PANTHER tool. Analysis type was selected as functional classification viewed in a pie chart. The pathway enrichment analysis of differentially expressed proteins identified from ProteinLynx Global Server ${ }^{\mathrm{rm}}$ v2.5.3 (PLGS, Waters Corporation), was done using g:Profiler web server (Fig. 3C) [39].

\section{Relative expression profiles of candidates from proteomics data}

Poly-house grown, 3 weeks old S. bicolor seedlings of - Swarna (susceptible) \& ICSV700, IS2205 (resistant) were used for gene expression analysis. C. partellus extract prepared in water was applied to mechanically wounded leaves to mimic the insect infestation (W + E). In control samples, wounding was followed by the application of water $(\mathrm{W}+\mathrm{W})$ to the leaf. Leaf samples were collected $3 \mathrm{~h}$ and $24 \mathrm{~h}$ post-treatment. Total RNA was extracted using the Macherey-Nagel NucleoSpin Plant II kit (Macherey Nagel Co., Duren, Germany) according to the manufacturer's instructions. The concentration of RNA was measured using Nano-Drop (Eppendorf, Biophotometer plus, 


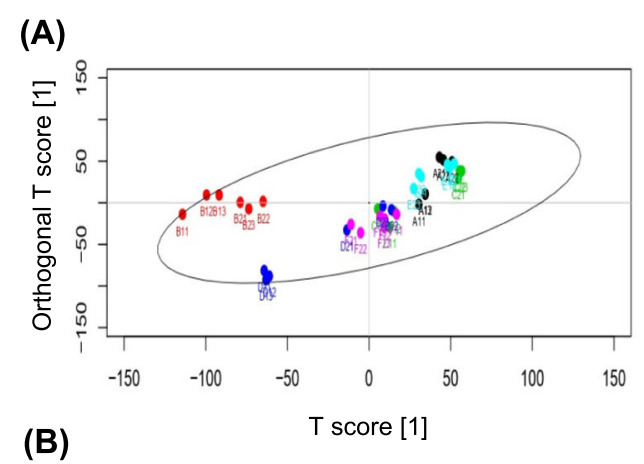

(C)
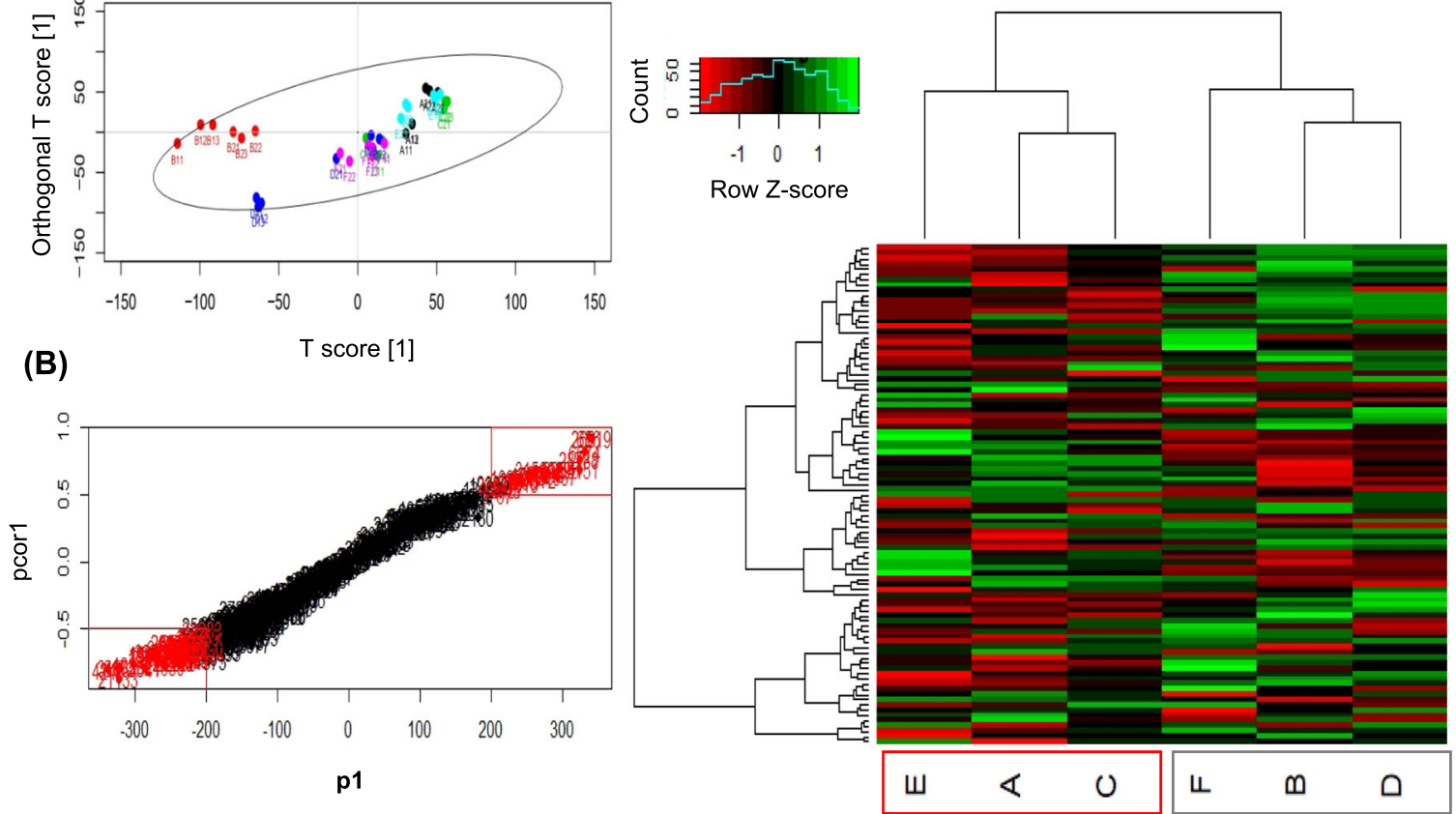

(D) $A \quad B \quad C \quad D \quad E \quad F$
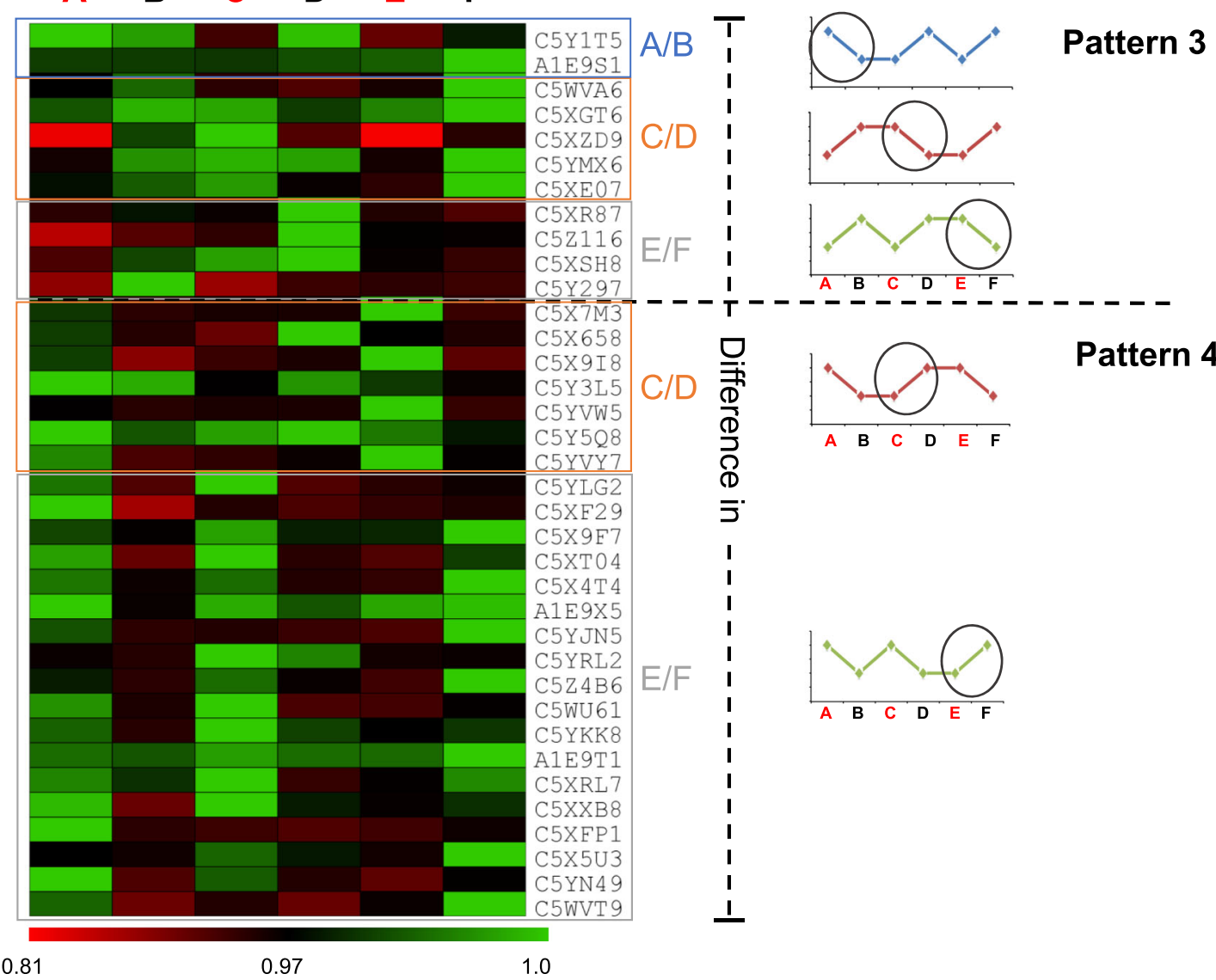

Pattern 3

Fig. 2 (See legend on next page.) 


\section{(See figure on previous page.)}

Fig. 2 Statistical multivariate analysis of S. bicolor- C. partellus proteomics study| (A) OPLS-DA score plot, indicates that the induced sorghum varieties tend to have positive values of T score as well as orthogonal T score (except for $\mathrm{C} 1$ ), whereas the un-induced varieties tend to have negative values of orthogonal T score (except for B2) (B) The S-plot obtained from OPLS-DA helps in identifying most significantly differentially expressed proteins in S. bicolor genotypes at steady-state and upon C. partellus infestation. (C) Clustering analysis was used to identify closeness in protein abundance and indicated the distinct signatures between treatments steady-state and C. partellus induced S. bicolor genotypes. Heatmap shows the variation in the protein expression across S. bicolor genotypes at steady-state and upon C. partellus infestation. (D) Heat map showing expression levels of proteins common yet differential amongst S. bicolor genotypes under various treatments - (A-F). Proteins from Pattern3 and Pattern4 have been normalized across rows and each row gives information about a single protein abundance indicated by the UniProt accession number on right. Proteins expressed in these patterns are differentially abundant (over-represented or under-represented) across insect-infested and steady-state comparisons. Graphs on the right, represent expression patterns of the proteins across treatments in resistant and susceptible S. bicolor genotypes

Hamburg, Germany). The integrity of RNA samples was checked by agarose gel electrophoresis and $2 \mu \mathrm{g}$ RNA was used for cDNA synthesis using a cDNA synthesis kit (High capacity cDNA Reverse Transcription kit, Applied Biosystems, Foster City, California, United States) as per the manufacturer's guidelines. Real-time quantitative PCR (7500 Fast real-time PCR systems, Applied Biosystems, Foster City, California, United States) was used to check expression levels of the candidates identified from proteomics analysis using gene-specific primers synthesized at IDT (Coralville, Iowa, United States) (Supplementary Table 3), with the help of GoTaq qPCR Master Mix (Promega Corporation, Madison, USA). Tubulin was used as a reference house-keeping gene for analysis. The data from 3 biological replicates of leaves were analyzed with 4 technical replicates each. Threshold cycle values $(\mathrm{Ct})$ were used to calculate $\Delta \mathrm{Ct}=\mathrm{Ct}_{\mathrm{Gene}}$ of interest $-\mathrm{Ct}_{\text {Tubulin }}$ and represented as fold change $2^{\Delta \mathrm{Ct}}$ in the graphs (Fig. 5). The uninduced control sets for all the 3 genotypes were compared and analyzed using Tukey's HSD test and indicated by different letters showing significant difference in expression values (Fig. 5). The water treatment $(W+W)$ and insect extract-treated samples $(W+E)$ were compared to the respective controls with the help of a two-tailed Student's t-test with unequal variance with the threshold of $p<0.05$.

\section{Results}

\section{C. partellus infestation induces differential shifts in leaf proteomes of three different $S$. bicolor genotypes}

The selected S. bicolor genotypes namely ICSV700, IS2205 and Swarna varied for their insect susceptibility/ resistance and other agronomic traits like plant height, panicle, flowering time, grain characters and grain mass (Table 3). The earlier studies had indicated that ICSV700 and IS2205 were having moderate to good resistance to insect pests respectively, while Swarna was insect susceptible, but displayed desirable agronomic traits namely early flowering, lower plant height and higher seed mass [30]. The leaf proteomics of these three S. bicolor genotypes at steady-state (uninduced) and induced with the insect pest $C$. partellus was carried out to identify the $S$. bicolor proteins responsible for insect resistance (Fig. 1). The proteome data consisted of 967 characterized proteins, of which 232 were commonly detected in all treatments, 93 were differentially abundant across treatments, proteins common to a subset of treatments namely -induced A, C, E and steadystate $B, D, F$ were 72 and 80 respectively, while the sum of proteins uniquely detected in each treatment (A-F) were 617. Multivariate analysis of the proteomics data in the form of PCA (Supplementary Fig. 1) and OPLS-DA was performed on all proteins identified in the study. The results indicated the overall distribution of the samples (A-F) and closeness of the biological and technical replicates (except C, D of the S. bicolor IS2205) (Fig. 2A). Based on their separation along the X-axis of OPLS-DA ( $\mathrm{T}$ score) the resistant $S$. bicolor genotype ICSV700 in the uninduced state (B) was strikingly different from the rest of the two. Moreover, upon C. partellus induction both the resistant genotypes ICSV700 (A) and IS2205 (C) showed a remarkable proteomic alteration as compared to their corresponding uninduced states $(\mathrm{B}, \mathrm{D})$ as indicated by the difference in the $\mathrm{T}$ score (Fig. 2A).

The S-plot helped demarcate the overall significantly differential proteins from the $S$. bicolor proteome (Fig. 2B) as detailed in (Table 2). Twenty two proteins from the upper end and 46 from the lower end of the S-plot were identified as significantly differential. Their gene ontology indicated that they were involved in defense and immunity, calcium-binding and signaling, cell wall modifications and catalytic activities; whereas the proteins with less abundance were mostly involved in translation, signaling, and different catalytic activities (Table 2 ). These proteins may positively or negatively regulate S. bicolor's interaction with C. partellus through their involvement in defense, biotic and abiotic stress tolerance, detoxification, enzyme inhibition, hydrolysis activities and signaling.

Cluster analysis was performed on the proteins commonly detected in all the treatments (A-F) (Fig. 2C). The 
Table 2 Summary of in solution proteomics study of leaves of three S. bicolor genotypes at steady-state \& upon C. partellus infestation

\begin{tabular}{|c|c|c|c|c|}
\hline Genotype & Sample code & Treatments & Tech. replicates & No. of proteins \\
\hline \multirow[t]{12}{*}{ ICSV700 (Resistant) } & $A$ & Infested & 1 & 384 \\
\hline & & & 2 & 291 \\
\hline & & & 3 & 347 \\
\hline & & Infested & 1 & 396 \\
\hline & & & 2 & 392 \\
\hline & & & 3 & 388 \\
\hline & B & Steady-state & 1 & 538 \\
\hline & & & 2 & 450 \\
\hline & & & 3 & 448 \\
\hline & & Steady-state & 1 & 367 \\
\hline & & & 2 & 313 \\
\hline & & & 3 & 355 \\
\hline \multirow[t]{12}{*}{ IS2205 (Resistant) } & C & Infested & 1 & 426 \\
\hline & & & 2 & 368 \\
\hline & & & 3 & 378 \\
\hline & & Infested & 1 & 380 \\
\hline & & & 2 & 359 \\
\hline & & & 3 & 338 \\
\hline & D & Steady-state & 1 & 483 \\
\hline & & & 2 & 421 \\
\hline & & & 3 & 425 \\
\hline & & Steady-state & 1 & 440 \\
\hline & & & 2 & 364 \\
\hline & & & 3 & 312 \\
\hline \multirow[t]{12}{*}{ Swarna (Susceptible) } & $\mathrm{E}$ & Infested & 1 & 324 \\
\hline & & & 2 & 290 \\
\hline & & & 3 & 298 \\
\hline & & Infested & 1 & 370 \\
\hline & & & 2 & 306 \\
\hline & & & 3 & 257 \\
\hline & $\mathbf{F}$ & Steady-state & 1 & 313 \\
\hline & & & 2 & 332 \\
\hline & & & 3 & 340 \\
\hline & & Steady-state & 1 & 347 \\
\hline & & & 2 & 327 \\
\hline & & & 3 & 289 \\
\hline
\end{tabular}

analysis indicated that the proteins from the uninduced S. bicolor samples (B, D, F) clustered separately from the C. partellus induced samples (A, C, E). Moreover, the insect-resistant S. bicolor genotypes namely ICSV700 and IS2205 (represented by A, B and C, D) clustered separately from the insect susceptible S. bicolor Swarna $(\mathrm{E}, \mathrm{F})$.
Ninety three proteins were found to be differentially expressed in the S. bicolor genotypes (A-F), of which 57 proteins displayed similar abundance patterns in the three S. bicolor genotypes (Supplementary Fig. 2), representing a fraction of defense response commonly induced by the genotypes upon $C$. partellus infestation. These protein species were further categorized into two 
patterns- Pattern 1 with 38 proteins downregulated upon C. partellus infestation and Pattern2 with 19 proteins upregulated upon C. partellus infestation in S. bicolor genotypes compared to the steady-state (Supplementary Fig. 2). The remaining 36 proteins were important as they were differentially abundant in the resistant and susceptible S. bicolor genotypes. They were further grouped into Pattern3 (11 proteins) and Pattern4 (25 proteins) representing under-represented and overrepresented proteins in C. partellus induced S. bicolor respectively, with contrast in protein expression displayed by one of the S. bicolor genotypes (Fig. 2D; Supplementary Fig. 3). Pattern3 proteins indicated that the biological process of translation was contrastingly upregulated in resistant S. bicolor genotypes. Proteins like Photosystem II subunit, germin-like protein, serine hydroxyl methyltransferase and ATPase alpha subunit were prominent in C. partellus induced susceptible Swarna (E) whereas they were under-represented in corresponding treatments of resistant genotypes, ICSV700 (A) and IS2205 (C). In the Pattern4 insect susceptible S. bicolor Swarna displayed an under-representation of the proteins which were involved in the biosynthetic process, cellular nitrogen compound process and cellular amino acid metabolism, represented by proteins like glycinerich protein 2, NAD $(\mathrm{P}) \mathrm{H}$-quinone oxidoreductase subunit, profilin-4, Co-chaperone CGE1 isoform b, cysteine synthase, non-specific lipid transfer protein and superoxide dismutase. Ribulose bisphosphate carboxylase, ATP synthase subunit beta, extracellular calciumsensing receptor and elongation factor 1- delta were upregulated in the $C$. partellus induced resistant $S$. bicolor genotype IS2205 (C) whereas they were underrepresented in the other genotypes.

\section{Analysis of differential proteins identified in a pairwise comparison of S. bicolor genotypes upon C. partellus infestation and at steady-state using ProteinLynx global server $^{\mathrm{TM}}$ v2.5.3 (PLGS, waters corporation)}

Leaf proteomes of $C$. partellus induced and steady states of genotypes of $S$. bicolor were compared with the help of ProteinLynx Global Server ${ }^{\mathrm{rm}}$ v2.5.3 (PLGS, Waters Corporation) to identify over-represented (fold change > 1.5 ) and under-represented (fold change $<0.65$ ) proteins. These proteins were compared to identify proteome similarities/differences amongst the genotypes (Fig. 3, Supplementary Data 1). Most of the differential proteins identified in the pair-wise comparisons were not shared

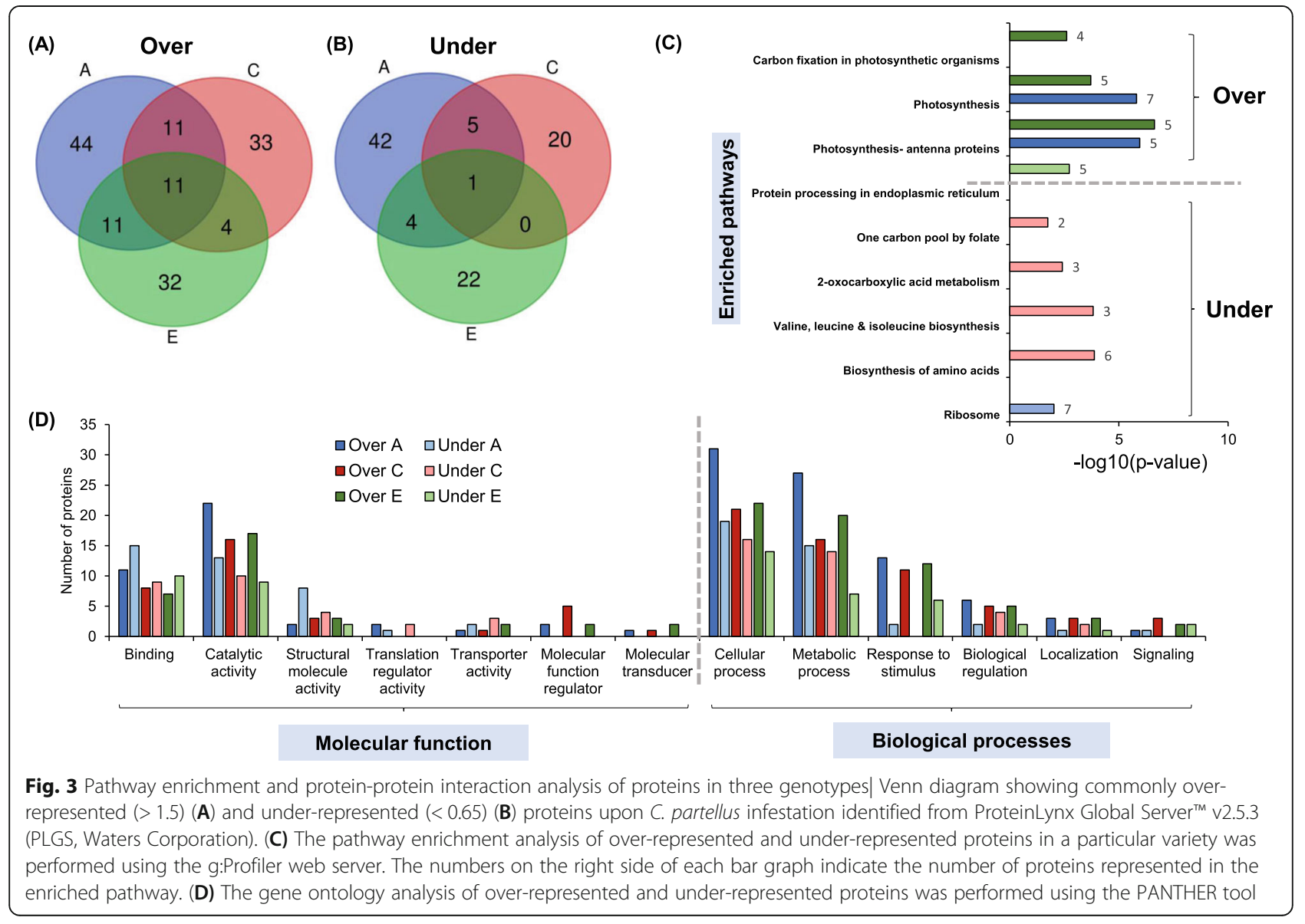


Table 3 Differentially abundant S. bicolor proteins identified from the S-plot analysis of the in solution proteomics data

\begin{tabular}{|c|c|c|c|c|}
\hline Status & $\begin{array}{l}\text { Protein } \\
\text { Key }\end{array}$ & $\begin{array}{l}\text { Protein } \\
\text { Accession } \\
\text { No. }\end{array}$ & Name of protein/similar protein & Function/ GO \\
\hline Up & 372 & C5X1U2 & Calmodulin & $\begin{array}{l}\text { Calcium ion binding (GO:0005509), calcium-mediated signaling } \\
\text { (GO:0019722) }\end{array}$ \\
\hline Up & 656 & C5YSK7 & $\begin{array}{l}\text { similar to Pathogenesis related } \\
\text { protein } 5\end{array}$ & Defense response (GO:0006952) \\
\hline Up & 1292 & C5YBE9 & $\begin{array}{l}\text { Chitin-binding type-1 domain- } \\
\text { containing protein }\end{array}$ & Chitinase activity (GO:0004568) \\
\hline Up & 1510 & C5YSK6 & $\begin{array}{l}\text { similar to Thaumatin like } \\
\text { pathogenesis related protein } 1\end{array}$ & Defense response (GO:0006952) \\
\hline Up & 5767 & C5ZON8 & Peroxidase & 2 phenolic donor $+\mathrm{H}_{2} \mathrm{O} 2=2$ phenolic radical donor $+2 \mathrm{H} 2$ \\
\hline Up & 6674 & C5XHS1 & similar to $\beta$-1,3-glucanase & $\begin{array}{l}\text { Hydrolysis of O-glycosyl compounds, Carbohydrate metabolic } \\
\text { process }\end{array}$ \\
\hline Up & 9254 & C5XCE2 & similar to Zeamatin-like protein & Inhibition of trypsin and a-amylases, Defense response (GO:0006952) \\
\hline Up & 9604 & C5Z469 & Peroxidase & 2 phenolic donor $+\mathrm{H}_{2} \mathrm{O} 2=2$ phenolic radical donor $+2 \mathrm{H} 2 \mathrm{O}$ \\
\hline Up & 10,330 & C5WZ07 & similar to Glutathione S-transferase & Glutathione transferase activity (GO:0004364) \\
\hline Up & 11,895 & C5YSV2 & $\begin{array}{l}\text { similar to Thaumatin like } \\
\text { pathogenesis related protein } 5\end{array}$ & Defense response (GO:0006952) \\
\hline Up & 12,145 & C5YYT5 & $\begin{array}{l}\text { similar to } 605 \text { acidic ribosomal } \\
\text { protein } \mathrm{P} 2 \mathrm{~B} \text { isoform } \mathrm{X} 1\end{array}$ & \\
\hline Up & 13,645 & C5Z3A0 & SCP domain-containing protein & similar to pathogenesis-related protein \\
\hline Up & 14,437 & C5WWX5 & similar to Histone2A & \\
\hline Up & 17,199 & C5Z9A2 & $\begin{array}{l}\text { similar to Thylakoid lumenal } 16.5 \\
\text { kDa protein }\end{array}$ & Photosystem II repair (GO:0010206) \\
\hline Up & 19,206 & C5WT31 & $\begin{array}{l}\text { similar to DPP6 N-terminal domain- } \\
\text { like protein }\end{array}$ & \\
\hline Up & 23,877 & C5YLY5 & similar to Ribosome-recycling factor & \\
\hline Up & 26,619 & C5Y817 & $\begin{array}{l}\text { similar to Carboxyl terminal } \\
\text { peptidase precursor }\end{array}$ & Peptidase activity \\
\hline Up & 26,971 & C5X8S2 & SCP domain-containing protein & Cysteine rich secretory protein, allergen V5/Tpx-1 \\
\hline Up & 28,788 & C5WQE1 & $\begin{array}{l}\text { similar to a-amylase/ trypsin } \\
\text { inhibitor }\end{array}$ & \\
\hline Up & 30,151 & C5Z8N5 & $\begin{array}{l}\text { Expansin-like EG45 domain- } \\
\text { containing protein }\end{array}$ & Chitinase activity \\
\hline Up & 31,567 & C5YGE3 & $\begin{array}{l}\text { similar to Abscisic acid stress } \\
\text { ripening } 3\end{array}$ & \\
\hline Up & 31,569 & C5Y5D6 & Barwin domain-containing protein & Defense response to bacterium (GO:0042742) or fungus (GO:0050832) \\
\hline Down & 34 & A1E9V4 & Cytochrome b6 & Component of the cytochrome b6-f complex \\
\hline Down & 102 & A1E9W6 & $\begin{array}{l}50 S \text { ribosomal protein } L 2 \text {, } \\
\text { chloroplastic }\end{array}$ & Mitochondrial translation (GO:0032543) \\
\hline Down & 121 & A1E9W0 & $\begin{array}{l}30 \text { ribosomal protein } \mathrm{S} 8 \text {, } \\
\text { chloroplastic }\end{array}$ & Translation (GO:0006412) \\
\hline Down & 260 & $\mathrm{C} 5 \mathrm{YH} 12$ & Caffeic acid O-methyltransferase & Flavonol biosynthetic process (GO:0051555) \\
\hline Down & 353 & C5XYX5 & $\begin{array}{l}\text { similar to } 605 \text { ribosomal protein } \\
\text { L11-1 }\end{array}$ & Translation (GO:0006412) \\
\hline Down & 1163 & C5X1Q1 & $\begin{array}{l}\text { similar to Hydroxyproline-rich glyco- } \\
\text { protein family protein }\end{array}$ & \\
\hline Down & 1442 & C5Y065 & Lipase_3 domain-containing protein & Lipid metabolic process (GO:0006629) \\
\hline Down & 1979 & C5YIF8 & Obg-like ATPase 1 & $\begin{array}{l}\text { ATPase activity (GO:00016887), Negative regulation of response } \\
\text { to salt stress (GO:1901001)\& defense response to bacterium (GO:1900425) }\end{array}$ \\
\hline Down & 3699 & C5YRK9 & $\begin{array}{l}\text { similar to Pentatricopeptide repeat- } \\
\text { containing protein }\end{array}$ & RNA modification (GO:0009451) \\
\hline
\end{tabular}


Table 3 Differentially abundant S. bicolor proteins identified from the S-plot analysis of the in solution proteomics data (Continued)

\begin{tabular}{|c|c|c|c|c|}
\hline Status & $\begin{array}{l}\text { Protein } \\
\text { Key }\end{array}$ & $\begin{array}{l}\text { Protein } \\
\text { Accession } \\
\text { No. }\end{array}$ & Name of protein/similar protein & Function/ GO \\
\hline Down & 4242 & C5XW30 & $\begin{array}{l}\text { similar to Phorphobilinogen } \\
\text { deaminase }\end{array}$ & $\begin{array}{l}\text { It catalyzes head to tail condensation of four porphobilinogen molecules } \\
\text { releasing } 4 \text { ammonia molecules }\end{array}$ \\
\hline Down & 5841 & C5YRL0 & Non-specific lipid transfer protein & $\begin{array}{l}\text { Bifunctional protease and alpha amylase inhibitor inhibitor, lipid binding (GO: } \\
\text { 0008289) lipid transfer (GO:0006869) protein }\end{array}$ \\
\hline Down & 6172 & C5XYT6 & $\begin{array}{l}\text { FAD_binding_3 domain-containing } \\
\text { protein }\end{array}$ & FAD binding (GO:0071949), Geranylgeranyl reductase activity (GO:0045550) \\
\hline Down & 10,362 & C5YL07 & Aldedh domain-containing protein & $\begin{array}{l}\text { Betaine-aldehyde dehydrogenase activity (GO:0008802), Response to anoxia } \\
\text { (GO:0071454) }\end{array}$ \\
\hline Down & 11,647 & C5WTC9 & $\begin{array}{l}\text { Ribosomal_L16 domain-containing } \\
\text { protein }\end{array}$ & Translation (GO:0006412) \\
\hline Down & 12,657 & C5Z267 & similar to 605 ribosomal protein $L 9$ & Cytoplasmic translation (GO:0002181) \\
\hline Down & 14,425 & C5YAD0 & similar to 605 ribosomal protein L6 & Cytoplasmic translation (GO:0002181) \\
\hline Down & 15,418 & C5XEA1 & $\begin{array}{l}\text { similar to Fructose-bisphosphate al- } \\
\text { dolase 1, chloroplastic isoform X1 }\end{array}$ & \\
\hline Down & 15,466 & C5YHF2 & similar to Rubredoxin family protein & \\
\hline Down & 15,661 & C5XZ84 & $40 \mathrm{~S}$ ribosomal protein $\mathrm{S} 8$ & Translation (GO:0006412) \\
\hline Down & 15,716 & C5WZ25 & Tubulin beta chain & $\begin{array}{l}\text { GTPase activity (GO:0003924), microtubule cytskeletal organization (GO: } \\
\text { 0000226) }\end{array}$ \\
\hline Down & 16,668 & C5YAl8 & Pyruvate kinase & $\begin{array}{l}\text { ATP }+ \text { pyruvate }=A D P+H++ \text { phosphoenolpyruvate, Glycolytic process (GO: } \\
\text { 0006096) }\end{array}$ \\
\hline Down & 17,564 & C5YCD5 & PfkB domain-containing protein & $\begin{array}{l}\text { Adenosine kinase activity (GO:0004001), Purine ribonucleoside salvage (GO: } \\
\text { 0006166) }\end{array}$ \\
\hline Down & 18,075 & C5YXW7 & $\begin{array}{l}\text { Guanosine nucleotide diphosphate } \\
\text { dissociation inhibitor }\end{array}$ & $\begin{array}{l}\text { Rab GTPase binding (GO:0017137), small GTPase mediated signal } \\
\text { transduction (GO:0007264) }\end{array}$ \\
\hline Down & 19,332 & C5X6V0 & $\begin{array}{l}\text { similar to Extracellular ribonuclease } \\
\text { LE }\end{array}$ & RNA catabolic process (GO:0006401) \\
\hline Down & 19,346 & C5YG66 & Aminomethyltransferase & $\begin{array}{l}\text { Aminomethyltransferase activity (GO:0004047), Glycine decarboxylation via } \\
\text { glycine cleavage system (GO:0019464) }\end{array}$ \\
\hline Down & 21,133 & C5YG29 & similar to 605 ribosomal protein & Translation (GO:0006412) \\
\hline Down & 22,396 & C5YCD6 & Phenylalanine ammonia-lyase & $\begin{array}{l}\text { L-phenylalanine }=\mathrm{NH} 4++ \text { trans-cinnamate, } \text { Cinnamic acid biosynthetic } \\
\text { process (GO:0009800), L-phenylalanine catabolic process (GO:0006559) }\end{array}$ \\
\hline Down & 22,977 & C5WT26 & $40 S$ ribosomal protein $\mathrm{S} 4$ & Translation (GO:0006412) \\
\hline Down & 23,733 & C5YX57 & $40 S$ ribosomal protein 54 & Translation (GO:0006412) \\
\hline Down & 23,995 & C5YU66 & $\begin{array}{l}\text { similar to Heat shock } 70 \mathrm{kDa} \text { protein } \\
4\end{array}$ & Stress response \\
\hline Down & 24,630 & C5YJP1 & $\begin{array}{l}\text { HATPase_c domain-containing } \\
\text { protein }\end{array}$ & $\begin{array}{l}\text { Unfolded protein binding (GO:0051082), Response to chlorate (GO:0010157), } \\
\text { heat (GO:0009408), salt stress (GO:0009651), water deprivation (GO:0009414) }\end{array}$ \\
\hline Down & 25,743 & C $5 \times 255$ & $\begin{array}{l}\text { similar to Formate tetrahydrofolate } \\
\text { ligase }\end{array}$ & \\
\hline Down & 25,986 & C5WXD2 & $\begin{array}{l}\text { similar to Protein TIC110, } \\
\text { chloroplastic }\end{array}$ & \\
\hline Down & 26,465 & C5XXT8 & Phenylalanine ammonia-lyase & $\begin{array}{l}\text { L-phenylalanine }=\mathrm{NH} 4++ \text { trans-cinnamate, Cinnamic acid biosynthetic } \\
\text { process (GO:0009800), L-phenylalanine catabolic process (GO:0006559) }\end{array}$ \\
\hline Down & 28,031 & C5XIT6 & Pectinesterase & $\begin{array}{l}{[(1 \rightarrow 4) \text {-a-D-galacturonosyl methyl ester }](\mathrm{n})+\mathrm{n} \mathrm{H} 2 \mathrm{O}=[(1 \rightarrow 4)-\mathrm{a}-\mathrm{D}-} \\
\text { galacturonosyl }](\mathrm{n})+\mathrm{n} \mathrm{H}++\mathrm{n} \text { methanol, cell wall modification }(\mathrm{GO} 0042545)\end{array}$ \\
\hline Down & 28,874 & C5YMU8 & $\begin{array}{l}\text { similar to Puromycin-sensitive } \\
\text { aminopeptidase }\end{array}$ & \\
\hline Down & 29,216 & C5YPWO & similar to ATP-citrate synthase & ATP binding (GO:0005524) \\
\hline Down & 30,618 & C5WZ87 & similar to Ribosomal protein $\mathrm{S9}$ & Translation (GO:0006412) \\
\hline Down & 30,990 & C5XI18 & S-adenosylmethionine synthase & $\mathrm{ATP}+\mathrm{H} 2 \mathrm{O}+\mathrm{L}$-methionine $=$ diphosphate + phosphate $+\mathrm{S}$-adenosyl-L- \\
\hline
\end{tabular}


Table 3 Differentially abundant S. bicolor proteins identified from the S-plot analysis of the in solution proteomics data (Continued)

\begin{tabular}{|c|c|c|c|c|}
\hline Status & $\begin{array}{l}\text { Protein } \\
\text { Key }\end{array}$ & $\begin{array}{l}\text { Protein } \\
\text { Accession } \\
\text { No. }\end{array}$ & Name of protein/similar protein & Function/ GO \\
\hline & & & & methionine, S-adenosylmethionine biosynthetic process (GO:0006556) \\
\hline Down & 31,330 & C5YNT6 & $\begin{array}{l}\text { S4 RNA-binding domain-containing } \\
\text { protein }\end{array}$ & $\begin{array}{l}\text { Translation (GO:0006412), Positive regulation of translational fidelity (GO: } \\
\text { 0045903) }\end{array}$ \\
\hline Down & 31,631 & C5WXA8 & $\begin{array}{l}\text { NADPH-protochlorophyllide } \\
\text { oxidoreductase }\end{array}$ & chlorophyllide $\mathrm{a}+\mathrm{NADP}+=\mathrm{H}++\mathrm{NADPH}+$ protochlorophyllide a \\
\hline Down & 31,939 & C5WZQ4 & similar to $50 S$ ribosomal protein $\mathrm{L} 6$ & Translation (GO:0006412) \\
\hline Down & 32,283 & C5XE18 & $40 \mathrm{~S}$ ribosomal protein SA & Cytoplasmic translation (GO:0002181), Translation (GO:0006412) \\
\hline Down & 32,318 & C5YFQ2 & $\begin{array}{l}\text { Ribosomal_S17_N domain- } \\
\text { containing protein }\end{array}$ & Translation (GO:0006412) \\
\hline Down & 32,520 & C5X0S2 & Uroporphyrinogen decarboxylase & $\begin{array}{l}4 \mathrm{H}++ \text { uroporphyrinogen III }=4 \mathrm{CO} 2+\text { coproporphyrinogen III, } \\
\text { Protoporphyrinogen IX biosynthetic process (GO:0006782) }\end{array}$ \\
\hline Down & 32,758 & C5YS19 & $\begin{array}{l}\text { SAM_MPBQ_MSBQ_MT domain- } \\
\text { containing protein }\end{array}$ & Methyltransferase activity (GO:0008168) \\
\hline
\end{tabular}

The OPLS-DA analysis followed by S-plot analysis was carried out to identify proteins from S. bicolor genotypes that showed significant differential abundance. The commonly expressed proteins identified from S. bicolor genotypes in all the treatments namely steady-state and C. partellus induced were considered for this analysis

between the 3 genotypes, signifying unique ways of each genotype to deal with the C. partellus induction (Fig. 3A $\& 3 B)$. The enrichment analysis of over-represented proteins from Swarna and ICSV700 is involved in photosynthesis or carbon fixation. Under-represented proteins were enriched for the ribosome, protein processing in the endoplasmic reticulum, biosynthesis of amino acids (Fig. 3C). The gene ontology analysis of these proteins indicated that the majority of them were involved in cellular and metabolic processes related to binding and catalytic activities. It is important to note that S. bicolor upon C. partellus infestation suppresses the accumulation of several proteins from these GO categories and initiates the accumulation of other proteins representing the same categories (Fig. 3D). Under-representation of proteins related to response to stimulus in Swarna was one interesting find from this analysis. To maximize the useful information derived from the data, the induced and un-induced states were compared separately in further analysis.

\section{GO analysis of differential proteins in $C$. partellus induced} S. bicolor (A, C, E) and S. bicolor at steady state (B, D, F) Comparing the insect-induced $(\mathrm{A}, \mathrm{C}, \mathrm{E})$ or steady-state (B, D, F) treatments across S. bicolor genotypes helped to widen the analysis by maximizing the information obtained (Fig. 4). The comparison amongst the three treatments led to the identification of a higher number of differential proteins and also account for the intrinsic differences amongst the varieties. The analysis was done on 72 and 80 proteins differentially abundant in C. partellus induced S. bicolor genotypes (A, C, E) or at steady state $(B, D, F)$ respectively (Supplementary Table 2 and Fig. 4). Of the set, a large number of protein species were significantly differentially abundant in the susceptible genotype Swarna than resistant genotypes. It represented the protein species through which both the resistant S. bicolor genotypes responded similarly to the C. partellus infestation. Intriguingly, protein species that were found to be differentially abundant in both the resistant S. bicolor genotypes either at steady state or upon C. partellus infestation were found to be involved in cellular metabolic processes, organic substance metabolic process, nitrogen compound and small molecule metabolic process, oxidation-reduction and response to abiotic stimuli (Fig. 4C). These proteins had the molecular function (MF) of binding and catalytic activity though these were represented by different proteins in A, C, E or B, D, F comparisons (Supplementary Table 2).

\section{The S. bicolor resistant genotypes are rich in unique proteins}

The resistant genotype ICSV700 was found to contain the highest number of unique proteins at steady-state (B) (180) followed by the other resistant S. bicolor IS2205 - (D) (135) while the C. partellus induced ICSV700 (A) also displayed around 105 unique proteins (Fig. 5). The GO analysis of the unique proteins identified in each indicated that the molecular functions such as catalytic activity, binding, structural molecular activity were represented predominantly from un-induced resistant genotypes, ICSV700 (B) and IS2205 (D) whereas these functions were very low in the susceptible variety, Swarna. The biological processes like cellular process, metabolic process, cellular component, localization, response to stimulus and cellular components like membrane, macromolecular complex, cell part, organelle 
(A)

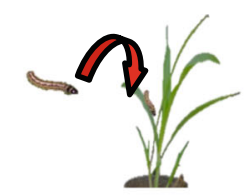

A C E

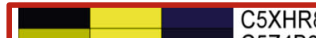

C5Z4B

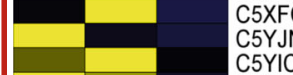

C5X4T
C5Y3X7
C5YT4
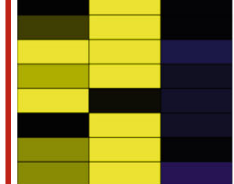

C5Y9W4

C5XT04

C5YLG2

C5XR31

Q9T2L6

C5YDD1

C5XCE2

C5XCE2
C5X768

C5X1U2

C5WU6

C5WRV

C5XJT8

C5YN49

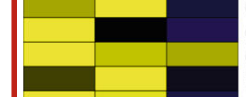

$5 Z 0 B 5$

B5B9V8

C5Z8N5

C5XBK5

C5YSV2

C5XE07

C5Z2S4

C.5YM153

C5XIL2

C5X972

C5YUB8

C5YIU7

C5X7N2

C5X0W1

C5X7Q2
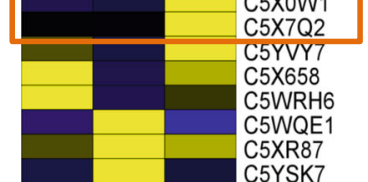

C5YSK

C5YSK7

C5YRL2

A1E9S3

A1E9S3

A1E9R0

A1E9T1

C5X9F7

C5XJW7

C5XJW

C5XSH8

C5YJQ8

C5YHK9

C5YMX6

C5XWZ7

Q4VQB2

C5YZJ4

C5XFP

$\mathrm{C}$ 26H7 7
C5XF29

C5XF29

C5Y1T5

C5YYX3

C5WVA6

A1E9T7

C5XC52

C5Z116

C5XQ07

C5WZ31

C5X8S2

C5Z269

C5Y817

C5XN16

(B)

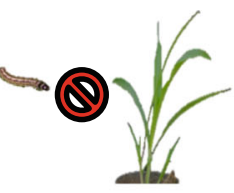

B D $F$

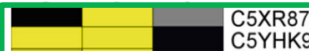

C5YHK9

C5Z529

C5XUF6

C5Z5R1
C5X4C8

C5WXA8

C5WYF2

C5YF84

C5YW13

C5WTL6

C5Y5Q8

C5X7M3

C5Y9W4

C5YMV5

C5Y3X7

C5X1V3

C5YMW4

C5Y3L5

C5XKV8

C5XVM4

C5X4S1

C5YPZ1

C5X7L1

C5YJ75

C5XXSO

C5X0U5

C5YJQ8

C5WX74

A1E9S3

C5XWJ8

C5XSH8

C5YH46

C5YH46

C5X0P2

C5X0W2

C5Yบ98

C5YU98
C5X3T9

C5YWW5

C5XSW9

C5Y7U2

C5YCZ2

C5WN47

C5YSP7

C5YSM6

C5WTC1

C5YCJ6

C5XDPO

C5YJN5

C5Y1T5

C5XA61

C5X658

C5YRL2

C5X0G5

C5XF29

C5YKK8

C5XXB8

C5XHR8

C6JSGO

C5XJZ3

C5Y596

C5YZJ4

C5Z8X0

C5YLK6

C5YIC3

Q84LQ5

C5WZ87

A1E9V0

C5XGT6

C5X1K7

C5WLV9

A1E9W6

A1E9Y0

A1E9Y0

C5XW45

C5XIT6

C5Y8Q1

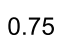

0.98
(C)

$$
\text { Signal transduction }
$$

Regulation of biological process

Cellular comp. organization

Regulation of biological quality

Response to chemical

ATP metabolic process

Cellular component biogenesis

Catabolic process

Response to stress

Cellular response to stimulus

Protein folding

Response to abiotic stimulus

Oxidation-reduction process

Biosynthetic process

Small mol. metabolic process

Nitrogen comp. met. process

Primary metabolic process

Organic substance met. proc.

Cellular metabolic process

Guanyl-nucleo. ex. fct. activity

$$
\text { Cofactor binding }
$$

Translation regulator activity

Lyase activity

Small molecular binding

Drug binding

Carbohydrate derv. binding

Oxidoreductase activity

Hydrolase activity

Protein binding

Structural const. of ribosome

Organic cyclic comp, binding

Heterocyclic comp. binding
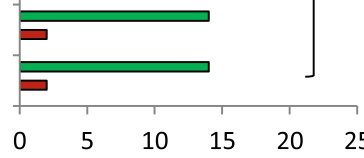

No. of proteins

Fig. 4 (See legend on next page.) 
(See figure on previous page.)

Fig. 4 GO analysis, protein abundance of differentially regulated proteins from C. partellus infested \& steady-state S. bicolor genotypes | 72 \& 80 proteins were found to be differentially expressed in S. bicolor genotypes under treatmetns - A, C, E (A) and - B, D, F (B) respectively. The heatmap was made by using log-transformed protein expression values normalized across rows. (A) Proteins represented with the box were over-represented (orange) and under-represented (red) in susceptible S. bicolor Swarna represented by treatment E compared to their levels in resistant genotypes ICSV700 and IS2205 upon C. partellus infestation, represented by treatments $A$ and C respectively. (B) Proteins represented with the box were over-represented (blue) and under-represented (green) in S. bicolor Swarna represented by treatment F, compared to the other two insect-resistant genotypes at a steady state represented by treatments B and D respectively. (C) GO level-2 analysis of proteins exhibiting distinct patterns across resistant \& susceptible genotype was indicated in the figure with molecular function, biological processes.

were also higher in unique proteins found in un-induced S. bicolor resistant genotypes, ICSV700 and IS2205.

The top 10 most abundant unique proteins from each sample (A-F) are listed in Table 4 . The C. partellus induced ICSV700 (A) showed the presence of proteins like $\beta$-caryophyllene synthase involved in indirect defense; RPP-13 like protein, Ankyrin repeat domain-containing protein 2, adenylyl cyclase associated protein which plays an important defense role in plants; proteins involved in protein turnover DNA repair, wound healing was also detected. Some interesting proteins like ATP synthase CF1 alpha subunit involved in inducing changes in plant surface structures like spines were also seen [40]. The other resistant genotype of S. bicolor IS2205 (C) upon C. partellus infestation showed the unique presence of plant defense proteins like chitinase, RPP-13 like; biotic and abiotic stress-related proteins like monogalactosyldiacyl glycerol synthase, zinc finger $\mathrm{CCh}$ domain-containing protein 55, thiazole synthase; and proteins involved in protein turn over. The susceptible S. bicolor upon C. partellus induction (E), however, showed the expression of proteins like kinases, proteins involved in growth, turnover and homeostasis like adenylate isopentyl transferase, ubiquitin E3-protein ligase, triacylglycerol lipase and UDP d-glucuronate decarboxylase.

The resistant S. bicolor genotypes ICSV700 and IS2205, at the steady-state level (B, D) and upon C. partellus infestation $(\mathrm{A}, \mathrm{C})$ had a far high number of unique proteins while susceptible $S$. bicolor Swarna displayed strikingly smaller number of unique proteins. The susceptible $S$. bicolor variety Swarna lacks the proteins involved in metabolic processes related to nitrogenous compounds, sulfur compounds, secondary metabolites and biosynthetic processes and after infestation by $C$. partellus, it is inefficient in the upregulation of nitrogen compound biosynthesis.

\section{Relative expression profiles of genes corresponding to protein candidates identified in S. bicolor-C. partellus interaction proteomics}

Serine hydroxymethyltransferase, germins, cyanate hydratase, $\beta$-glucanases, lipid transfer proteins (LTP), zeamatin like proteins, endochitinases, superoxide dismutase (SOD), chaperonins and 14-3-3 like proteins were selected for gene expression analysis based on their protein expression pattern in non-targeted $S$. bicolor proteomics study as well as their function. We set up an independent experiment (methods section 2.6) to study the candidate gene expression kinetics at early time points $(3 \mathrm{~h}, 24 \mathrm{~h})$ after mimicking insect infestation.

The gene expression studies were carried out in the three genotypes of S. bicolor (ICSV700, IS2205 and Swarna) under treatments namely (i) steady-state, (ii) wounding $+C$. partellus extract application $(\mathrm{W}+\mathrm{E})$ and (iii) wounding + water application $(\mathrm{W}+\mathrm{W})$ at $3 \mathrm{~h}$ and $24 \mathrm{~h}$ post-treatment (Fig. 6). C. partellus extract application on the wounded leaf was done to mimic the insect herbivory on $S$. bicolor plants grown in the polyhouse. Distinct gene expression patterns were noted amongst the $S$. bicolor genotypes at steady state. Additionally, the $\mathrm{W}+\mathrm{E}$ and $\mathrm{W}+\mathrm{W}$ treatments also displayed differential gene expression patterns at $3 \mathrm{~h}$ and $24 \mathrm{~h}$ post-treatment across the $S$. bicolor genotypes. ICSV700 showed overexpression of germins, cyanate hydratase, LTP, zeamatin, endochitinase, chaperonins in $\mathrm{W}+\mathrm{E}$; whereas serine hydroxymethyltransferases, $\beta$ - glucanase, SOD, 14-3-3 like proteins were under-expressed in $\mathrm{W}+\mathrm{E}$. In $\mathrm{W}+\mathrm{E}$, IS2205 genotype showed over-expression of serine hydroxymethyltransferases, germins, SOD, chaperonins and downregulation of cyanate hydratase, $\beta$ - glucanase, 14-3-3 like proteins. While the susceptible genotype showed over-expression of LTP, chaperonins, and downregulation of cyanate hydratase, endochitinase, zeamatin and 14-3-3 like protein in $\mathrm{W}+\mathrm{E}$.

Over-expression of LTP and chaperonins and underexpression of 14-3-3 like proteins upon insect extract treatment were commonly observed across resistant and susceptible genotypes in W $+\mathrm{E}$. Germins were differentially over-expressed in resistant genotypes in $\mathrm{W}+\mathrm{E}$ treatment. Over-expression of zeamatin, endochitinase, cyanate hydratase was observed in ICSV700 while serine hydroxymethyltransferases, SOD were abundant in IS2205 in W + E treatment. The differences in overexpressed proteins in $\mathrm{W}+\mathrm{E}$ in resistant genotypes suggest that they have different mechanisms to confer the resistance to the insect pest. Except for LTP and chaperonins, the susceptible genotype Swarna is not able to overexpress the genes which have a putative role in defense against the insect. The relative expression 


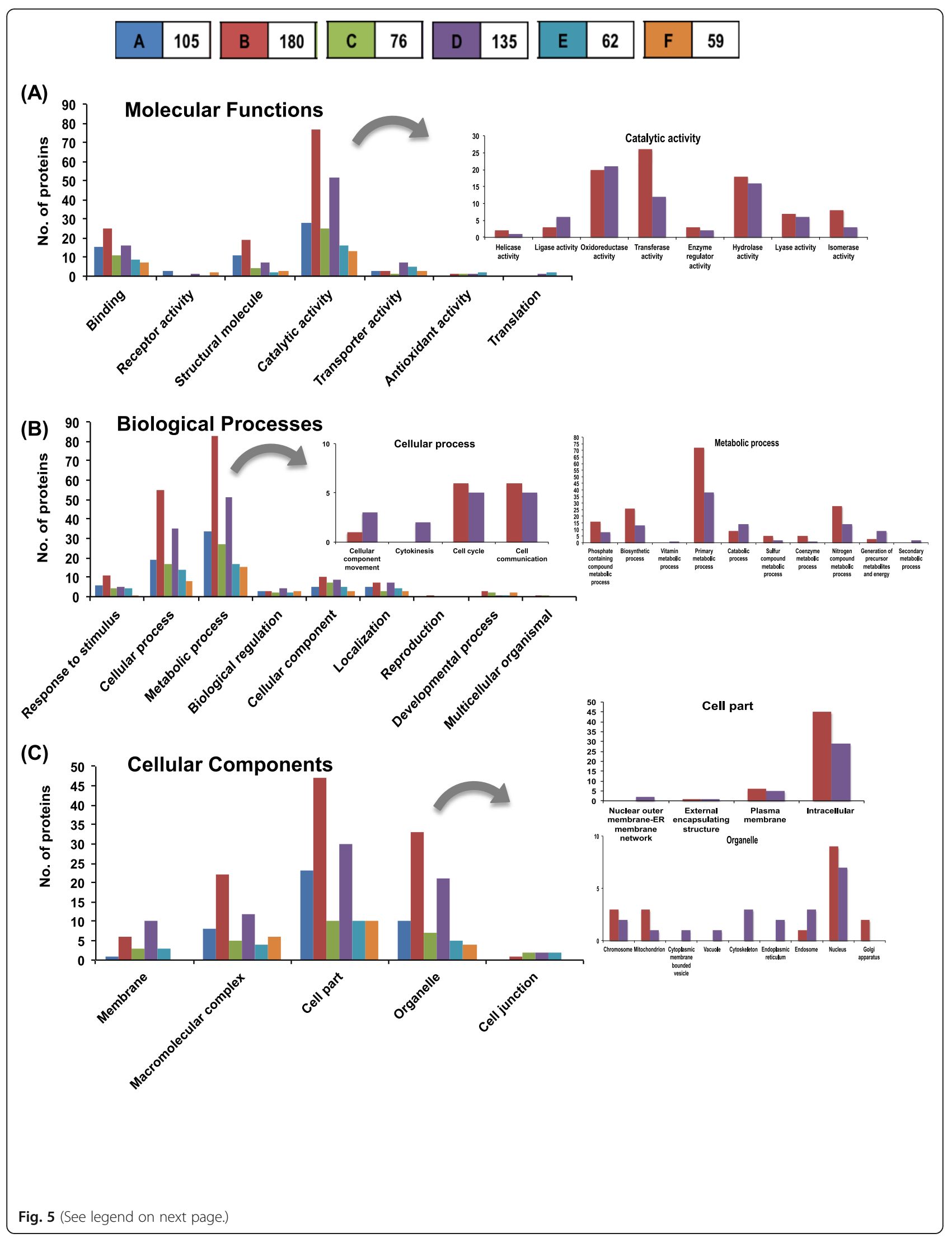


(See figure on previous page.)

Fig. $5 \mathrm{GO}$ analysis of uniquely detected proteins in S. bicolor genotypes| The proteomic analysis led to the identification of a large number of uniquely detected proteins in S. bicolor genotypes and treatments abbreviated as A, B, C, D, E, F. The horizontal strip with alphabet and number represents treatment and the corresponding number of unique proteins detected. GO analysis of unique proteins involved in molecular function $(\mathbf{A})$, biological process $(\mathbf{B})$ and cellular component $(\mathbf{C})$ have been displayed. The graphs in the insets represent the sub-categories of highly represented proteins

pattern of genes in early time points ( $3 \mathrm{~h}$ and $24 \mathrm{~h}$ ) post treatment was correlated to the late (20 days after initiating $C$. partellus infestation) expression profile of proteins identified from non-targeted proteomic studies. Proteins like zeamatin, endochitinase showed a correlation in early gene expression and late protein expression pattern whereas, serine hydroxymethyltransferase, SOD, chaperonins, 14-3-3 like proteins showed a partial correlation across timepoints and genotypes. LTP and $\beta$ - glucanase showed no correlation between the early gene expression and the late protein expression profile.

\section{Discussion}

Our study originated from the observations that the two genotypes of S. bicolor, ICSV700 and IS2205 are resistant to insect pests while the genotype Swarna is susceptible [1]. Proteins being one of the direct effector molecules against the insects, proteomic study on these genotypes would reveal many secrets about the plant defense [41]. We carried out a comparative proteomic analysis of S. bicolor $-C$. partellus interaction to identify the major protein components from $S$. bicolor genotypes responsible for resistance to $C$. partellus (Fig. 1). The study was focused on 967 characterized proteins from the $S$. bicolor proteome, their analysis which allowed us to investigate the intrinsic differences in the three genotypes of $S$. bicolor and analyze their proteomic response when induced by the pest $C$. partellus. This led to the identification of several proteins that strongly supported the insect resistance traits in S. bicolor genotypes, and will be important for further studies.

The study revealed that the three $S$. bicolor genotypes differentially responded to the induced infestation by $C$. partellus and also had intrinsically different proteomes at steady state levels (Fig. 2A, C). Plant domestication has led to changes in the crop plant defense pathways leading to their susceptibility (as seen in the genotype Swarna) to pests and pathogens [42], while their wild relatives and improved lines (like S. bicolor genotypes - ICSV700, IS2205) possess the molecular components contributing to their defense [43, 44]; the proteomic analysis of these genotypes helped in discovering the protein networks involved in strengthening plant defense to insect pests.

\section{The differential protein complements from S. bicolor genotypes in response to $C$. partellus}

Sixty eight proteins with differential abundance across $S$. bicolor genotypes at steady state and upon C. partellus infestation were identified and they were classified as significantly high or low abundance proteins (Fig. 2B; Table 2). The catalytic activities of abundant proteins were endochitinases, peroxidases and glutathione Stransferase like, all involved in promoting defense against insect pests; whereas the catalytic activities of less abundant proteins were flavone/caffeic acid 3-Omethyltransferase, ATP citrate synthase and betaine aldehyde dehydrogenase involved in the biosynthesis of a multitude of small molecules and methylated flavonoids useful in herbivore deterrence and abiotic stress $[45,46]$.

Cellular signaling machinery like Calmodulin-related proteins or G-protein and $\mathrm{G}$ protein modulators, various kinases, heat shock proteins, phenylalanine ammonialyase, were identified and need functional characterization to determine their contribution to $S$. bicolor pest resistance $[47,48]$. Additionally, the known defense proteins like PR-5, alpha-amylase/trypsin inhibitor, osmotin, non-specific lipid transfer protein were also amongst the candidates identified, reinforcing their role in plant defense against insect pests $[49,50]$.

Enrichment analysis of over-represented and underrepresented proteins have helped to gain a bird's eye view of the proteome remodeling upon $C$. partellus infestation in S. bicolor genotypes (Fig. 3). Overall, there is more protein suppression; and selective protein accumulation as represented by the higher number of proteins in 'response to stress' category. The underrepresentation of proteins involved in translation and amino acid biosynthesis was conspicuous and as expected; but the accumulation of proteins involved in the protection and maintenance of photosynthesis upon $C$. partellus infestation, is a feature that contrasts other reports [51].

\section{C. partellus resistant S. bicolor genotypes have commonalities in their proteome which are not detected in the susceptible S. bicolor Swarna}

S. bicolor Swarna had less abundance of proteins involved in defense, signaling and protein remodeling which might negatively influenc its defense against the invading lepidopteran pest (Fig. 2D; Supplementary Fig. 3; Supplementary Table 1). Swarna was seen to have high levels of PR proteins which are generally directed to deter pathogen attack, while the resistant S. bicolor genotypes are seen respond by signaling the activation of certain proteins having broad-spectrum activity against 
Table 4 Top 10 of the uniquely represented proteins from S. bicolor genotypes at steady-state and upon C. partellus infestation

\begin{tabular}{|c|c|c|}
\hline Key & $\begin{array}{l}\text { Protein } \\
\text { Accession No. }\end{array}$ & Protein Name \\
\hline \multicolumn{3}{|c|}{ A - S. bicolor ICSV700 infested by C. partellus } \\
\hline $\begin{array}{l}23 \\
819\end{array}$ & C5Y853 & similar to ATP synthase CF1 alpha subunit \\
\hline 1056 & C5WWL7 & similar to Beta-caryophyllene synthase \\
\hline 38 & C5YUK3 & Flap endonuclease 1-A \\
\hline 107 & A1E9R4 & DNA-directed RNA polymerase subunit beta \\
\hline 9314 & C5X5B2 & $\begin{array}{l}\text { similar to ADP-ribosylation factor GTPase-activating } \\
\text { protein AGD3 }\end{array}$ \\
\hline $\begin{array}{l}19, \\
695\end{array}$ & C5Y746 & $\begin{array}{l}\text { similar to disease resistance RPP13-like protein } 3 \\
\text { isoform X3 }\end{array}$ \\
\hline $\begin{array}{l}28, \\
942\end{array}$ & C5YHK1 & $\begin{array}{l}\text { similar to Ankyrin repeat domain-containing } \\
\text { protein } 2\end{array}$ \\
\hline 1890 & C5XAM0 & similar to ubiquitin-like \\
\hline $\begin{array}{l}20, \\
222\end{array}$ & C5X7K7 & similar to RNA polymerase beta subunit \\
\hline 4393 & C5YLQ0 & Adenylyl cyclase-associated protein \\
\hline
\end{tabular}

\section{B - S. bicolor ICSV700 at steady state}

$\begin{array}{lll}3162 & \text { C5YWC5 } & \text { similar to Proliferation-associated protein 2G4 } \\ 28, & \text { C5Z4X4 } & \begin{array}{l}\text { similar to reverse transcriptase, Brassinosteroid } \\ \text { insensitive-1 like }\end{array} \\ 7943 & \text { C5XJ50 } & \begin{array}{l}\text { similar to Retrotransposon protein } \\ 13,\end{array} \\ 397 & \text { C5WSY0 } & \text { similar to Arginine decarboxylase } \\ 27, & \text { C5XAT9 } & \text { Histone H2A } \\ 809 & & \\ 2862 & \text { C5XTG6 } & \text { Nitrate reductase } \\ 11, & \text { C5WU06 } & \text { similar to FACT complex subunit SPT16 } \\ 807 & & \\ 25, & \text { C5X957 } & \text { Ribosomal protein L15 } \\ 101 & & \\ 14, & \text { C5WQ44 } & \text { similar to enolase } \\ 173 & & \\ 16, & \text { C5YDV5 } & \text { similar to putative quinone oxidoreductase } \\ 161 & & \end{array}$

\section{C - S. bicolor IS2205 infested by C. partellus}

$\begin{array}{lll}29, & \text { C5YIU1 } & \text { similar to Monogalactosyldiacyl glycerol synthase 2 } \\ 614 & & \\ 13, & \text { C5YMZ5 } & \begin{array}{l}\text { similar to Zinc finger CCCH domain-containing } \\ \text { protein 55-like }\end{array} \\ 788 & & \begin{array}{l}\text { similar to ATP binding protein } \\ 9243 \text { C5WNH3 }\end{array} \\ 5008 \text { C5YGI4 } & \text { similar to thiazole synthase } \\ 25, & \text { C5YJ73 } & \text { similar to Ubiquitin and WLM domain-containing }\end{array}$

\section{Function}

Chloroplastic, correlation with spiny-ness

Indirect defense against Lepidoptera by attracting predators

Catalysis of the cleavage of a $5^{\prime}$ flap structure in DNA, but not other DNA structures; processes the $5^{\prime}$ ends of Okazaki fragments in lagging strand DNA synthesis, Acts as a genome stabilization factor

DNA-dependent RNA polymerase catalyzes the transcription of DNA into RNA using the four ribonucleoside triphosphates as substrates, Nucleoside triphosphate + RNA(n) $=$ diphosphate + RNA $(n+1)$

Binds to and increases the activity of a GTPase, plasma membrane remodeling

Disease resistance against pathogens

Chloroplast targeting sequence binding

Protein turnover

RNA polymerization

Cyclase-associated protein 1-like, cytoskeleton organization, response to pathogen

Change in state or activity of a cell or an organism as a result of a cytokinin stimulus

Plant architecture

Probable member of endonuclease, exonuclease, phosphatase family

Drought tolerance, defense

DNA binding, chromatin silencing

Cell signaling \& survival under stress

Histone binding and remodeling outside the context of DNA replication

Structural constituent of ribosome, Cytoplasmic translation

Phosphopyruvate hydratase activity

Oxidoreductase activity, chloroplastic

Thylakoid membrane biogenesis under stress

ABA biosynthesis, drought, post-transcriptional regulation of gene expression

Protein kinase activity, Serine/Threonine protein kinase STY46 like ADP binding, Cell wall integrity, and stress response component 1like

Ubiquitin and WLM domain-containing metalloprotease 
Table 4 Top 10 of the uniquely represented proteins from S. bicolor genotypes at steady-state and upon C. partellus infestation (Continued)

\begin{tabular}{|c|c|c|c|}
\hline Key & $\begin{array}{l}\text { Protein } \\
\text { Accession No. }\end{array}$ & Protein Name & Function \\
\hline 363 & & protein & \\
\hline 5014 & $\mathrm{C} 5 \times \mathrm{XCO}$ & $\begin{array}{l}\text { similar to Protein kinase domain-containing } \\
\text { protein }\end{array}$ & $\begin{array}{l}\text { Triggered in response to the presence of a foreign body or } \\
\text { the occurrence of an injury, Introducing a phosphate group } \\
\text { on to a protein, ATP binding, Cysteine-rich receptor-like } \\
\text { protein kinase } 26\end{array}$ \\
\hline 702 & C5X8K4 & similar to disease-resistant protein RPP-13 like 1 & Disease resistance protein against pathogen \\
\hline $\begin{array}{l}17, \\
789\end{array}$ & C5Z5B4 & $\begin{array}{l}\text { similar to } 265 \text { protease regulatory subunit } \\
6 \mathrm{~A} \text {-like protein }\end{array}$ & $\begin{array}{l}\text { ATP binding, Interacting selectively and non-covalently with a } \\
\text { member of the class of TATA-binding proteins (TBP), including } \\
\text { any of the TBP-related factors (TRFs), 26S protease regulatory } \\
\text { subunit 6A homolog }\end{array}$ \\
\hline $\begin{array}{l}19, \\
253\end{array}$ & $\mathrm{C} 5 \mathrm{YVH} 3$ & 605 acidic ribosomal protein P0 & Ribosomal subunit rRNA binding, Cytoplasmic translation \\
\hline $\begin{array}{l}21 \\
882\end{array}$ & C6JSVO & similar to Chitinase & $\begin{array}{l}\text { Catalysis of the hydrolysis of (1-> 4)-beta linkages of } \\
N \text {-acetyl-D-glucosamine (GlcNAc) polymers of chitin and } \\
\text { chitodextrins }\end{array}$ \\
\hline \multicolumn{4}{|c|}{ D - S. bicolor IS2205 at steady state } \\
\hline $\begin{array}{l}28, \\
234\end{array}$ & C5Y227 & $\begin{array}{l}\text { similar to Indole-3-acetic acid-amido } \\
\text { synthetase GH3.3 }\end{array}$ & $\begin{array}{l}\text { Synthesis of IAA-conjugates, a mechanism to cope up with } \\
\text { excess auxin }\end{array}$ \\
\hline $\begin{array}{l}22, \\
121\end{array}$ & C5X8X8 & $\begin{array}{l}\text { similar to AT-hook motif-containing protein, } \\
\text { Helicase }\end{array}$ & $\begin{array}{l}\mathrm{NTP}+\mathrm{H} 2 \mathrm{O}=\mathrm{NDP}+\text { phosphate, to drive the unwinding of a } \\
\text { DNA helix, Process of restoring DNA after damage, Telomere } \\
\text { maintenance, ATP-dependent DNA helicase PIF1-like }\end{array}$ \\
\hline 125 & C5XNN6 & Thiamine thiazole synthase 1 , chloroplastic & $\begin{array}{l}\text { Involved in the biosynthesis of the thiamine precursor thiazole, } \\
\text { Suicide enzyme, Additional roles in adaptation to various stress } \\
\text { conditions and DNA damage tolerance }\end{array}$ \\
\hline 6474 & C5WWV5 & $\begin{array}{l}\text { similar to Inactive ubiquitin carboxyl-terminal } \\
\text { hydrolase } 53\end{array}$ & $\begin{array}{l}\text { Thiol-dependent ubiquitinyl hydrolase activity, protein } \\
\text { deubiquitination, inactive ubiquitin carboxyl-terminal } \\
\text { hydrolase } 53\end{array}$ \\
\hline $\begin{array}{l}16, \\
964\end{array}$ & C5YS29 & similar to Diaminopimelate decarboxylase & $\begin{array}{l}\text { Diaminopimelate decarboxylase activity, } \\
\text { meso-2,6-diaminopimelate }+\mathrm{H}(+)=\mathrm{L} \text {-lysine }+\mathrm{CO}(2) \text {, systemic } \\
\text { acquires resistance }\end{array}$ \\
\hline $\begin{array}{l}31 \\
822\end{array}$ & C5XSW5 & Glutaredoxin-like protein & Photooxidative stress, antioxidant activity \\
\hline $\begin{array}{l}19, \\
098\end{array}$ & C5Z949 & $\begin{array}{l}\text { similar to RING zinc finger domain } \\
\text { superfamily protein }\end{array}$ & $\begin{array}{l}\text { Ubiquitin specific protease binding, ERAD-associated E3 } \\
\text { ubiquitin-protein ligase HRD1-like isoform X1 }\end{array}$ \\
\hline 2715 & C5XIX0 & $\begin{array}{l}\text { similar to NEFA-interacting nuclear protein } \\
\text { NIP30 }\end{array}$ & Protein FAM192A isoform X1 \\
\hline $\begin{array}{l}23 \\
386\end{array}$ & C5Y1Y1 & Peroxidase & 2 phenolic donor $+\mathrm{H}_{2} \mathrm{O}_{2}=2$ phenoxyl radical of the donor $+2 \mathrm{H}_{2} \mathrm{O}$ \\
\hline $\begin{array}{l}29 \\
401\end{array}$ & C5Z7K8 & $\begin{array}{l}\text { Pyruvate dehydrogenase E1 component } \\
\text { subunit alpha }\end{array}$ & Catalyzes the overall conversion of pyruvate to acetyl- $\mathrm{CoA}$ and $\mathrm{CO}_{2}$ \\
\hline
\end{tabular}

\section{E - S. bicolor Swarna infested by C. partellus}

2587 C5XAW9

21, C5XLE9

100

21, C5XXY

351

13, C5YV23

794

23. C5WW05

585

17, C5YTBO
Serine/threonine-protein kinase

similar to Photosystem II CP47 reaction center protein

similar to Serine-threonine kinase receptor-associated protein

similar to Adenylate isopentenyl transferase-like

similar to Triacylglycerol lipase SDP1

similar to Inosine-5'-monophosphate dehydrogenase
ATP + a protein $=A D P+$ a phosphoprotein, reactions triggered in prevention/recovery from the infection caused by the attack

Chlorophyll-binding, Photosynthetic ETS, Similar to Photosystem II CP47 chlorophyll apoprotein

Involved in defense

Cytokinin biosynthesis

Hydrolase activity, Catalysis of the reaction:

triacylglycerol $+\mathrm{H}_{2} \mathrm{O}=$ diacylglycerol + a carboxylate, membrane protein homeostasis

Serine/Threonine Kinase activity 
Table 4 Top 10 of the uniquely represented proteins from S. bicolor genotypes at steady-state and upon C. partellus infestation (Continued)

\begin{tabular}{|c|c|c|c|}
\hline Key & $\begin{array}{l}\text { Protein } \\
\text { Accession No. }\end{array}$ & Protein Name & Function \\
\hline 550 & & Kinesin-like protein & \\
\hline 6258 & C5YWV3 & similar to UDP-D-glucuronate decarboxylase & \\
\hline 349 & C5XT35 & $\begin{array}{l}\text { NADP-dependent D-sorbitol-6-phosphate } \\
\text { dehydrogenase }\end{array}$ & Oxidoreductase activity, sorbitol metabolism, development \\
\hline $\begin{array}{l}28, \\
758\end{array}$ & C5Y3U1 & similar to BOl-related E3 ubiquitin-protein ligase 1 & Abiotic stress tolerance, protein turnover \\
\hline $\begin{array}{l}13 \\
628\end{array}$ & C5YHS5 & $\begin{array}{l}\text { similar to } 5^{\prime} \text {-methylthioadenosine/ } \\
\text { S-adenosylhomocysteine nucleosidase } 2\end{array}$ & Catalytic activity, nucleoside metabolic process \\
\hline \multicolumn{4}{|c|}{ F - S. bicolor Swarna at steady state } \\
\hline $\begin{array}{l}17 \\
459\end{array}$ & C5WPC8 & similar to MAR-binding protein & The nuclear envelope protein, development \\
\hline $\begin{array}{l}18 \\
191\end{array}$ & C5Y2G1 & similar to Filamin B like protein & Connects cell membrane constituents to actin filaments \\
\hline $\begin{array}{l}23 \\
144\end{array}$ & C5X4Q7 & Histone $\mathrm{H} 2 \mathrm{~B}$ & DNA binding, Nucleosome assembly \\
\hline $\begin{array}{l}30, \\
485\end{array}$ & C5XZI6 & $\begin{array}{l}\text { similar to B-cell receptor-associated protein } \\
31 \text {-like containing protein }\end{array}$ & $\begin{array}{l}\text { ER to Golgi vesicle-mediated transport, Intracellular protein } \\
\text { transport, B cell receptor-associated protein } 31\end{array}$ \\
\hline 4299 & C5YXD6 & similar to Retrotransposon protein & Nucleic acid-binding, zinc ion binding, bZIP like protein \\
\hline $\begin{array}{l}16 \\
841\end{array}$ & C5YBM1 & Carboxypeptidase & Serine-type carboxypeptidase activity \\
\hline 7517 & $\mathrm{C} 5 \mathrm{Z7H} 3$ & $\begin{array}{l}\text { similar to Putative pentatricopeptide } \\
\text { repeat-containing protein }\end{array}$ & Zinc ion binding, RNA binding, splicing \\
\hline $\begin{array}{l}14 \\
188\end{array}$ & C5X6D0 & Lon protease homolog, mitochondrial & $\begin{array}{l}\text { ATP-dependent serine protease that mediates the selective } \\
\text { degradation of misfolded, unassembled or oxidatively damaged } \\
\text { polypeptides as well as certain short-lived regulatory proteins in } \\
\text { the mitochondrial matrix, protein homeostasis }\end{array}$ \\
\hline $\begin{array}{l}21 \\
520\end{array}$ & C5XXE4 & Similar to the nuclear mitotic apparatus protein 1 & Mitosis \\
\hline 2898 & C5Y2Y9 & similar to Clathrin heavy chain 1 & Present in a coat of vesicles \\
\hline
\end{tabular}

Many proteins were found to be uniquely accumulated in specific genotypes and treatments. The top 10 of these unique proteins were selected based on their intensity values obtained from the in solution proteomics. The table provides the details of the proteins and their functional significance

pathogens and pests or specifically directed against the pest. These are represented by proteins like chitinases, polyphenol oxidases and zeamatin.

The analysis of Pattern3 and Pattern4 proteins led to commonly expressed yet differentially abundant proteins across treatments. Serine hydroxymethyltransferase, from Pattern3, known for constitutive expression of salicylic acid-inducible genes and $\mathrm{H}_{2} \mathrm{O}_{2}$ detoxification genes [52] responsible for reducing the endogenous oxidative stress, was over-represented in the susceptible S. bicolor unlike resistant ICSV700 \& IS2205 genotypes (Fig. 2D; Supplementary Table 1). It was observed in previous studies that conditions favoring oxidative stress lead to redox signaling and hormonal crosstalk responsible for fine-tuning, enhancing the defense responses in plants [53]. Further, Swarna could not accumulate proteins involved in maintaining photosynthesis upon infestation by $C$. partellus like the resistant genotypes of S. bicolor as represented by Pattern4. In the pair wise comparison of proteins expressed before and after infestation by $C$. partellus in the $S$. bicolor genotypes, a number of distinct proteins were identified (Fig. 3, Supplementary Data 1). Photosynthesis related proteins were strongly upregulated in ICSV700 and Swarna upon C. partellus infestation, however IS2205 was seen to show least perturbations as indicated by the pathway analysis (Fig. 3C). Susceptible Swarna genotype may lack networks for fine-tuning of defense responses manifested by the absence or less abundance of several proteins detected in resistant genotypes.

The insect-resistant $S$. bicolor genotypes were enriched with elongation factors and chaperons, represented by proteins 14-3-3 like proteins, calmodulins, heat shock proteins and glutamine synthetase signifying an accelerated protein synthesis, downstream signaling and refolding activity upon infestation (Fig. 4A, C; Supplementary Table 2). Similar proteomic turnover has been demonstrated recently in wheat plants as a response to the pest 


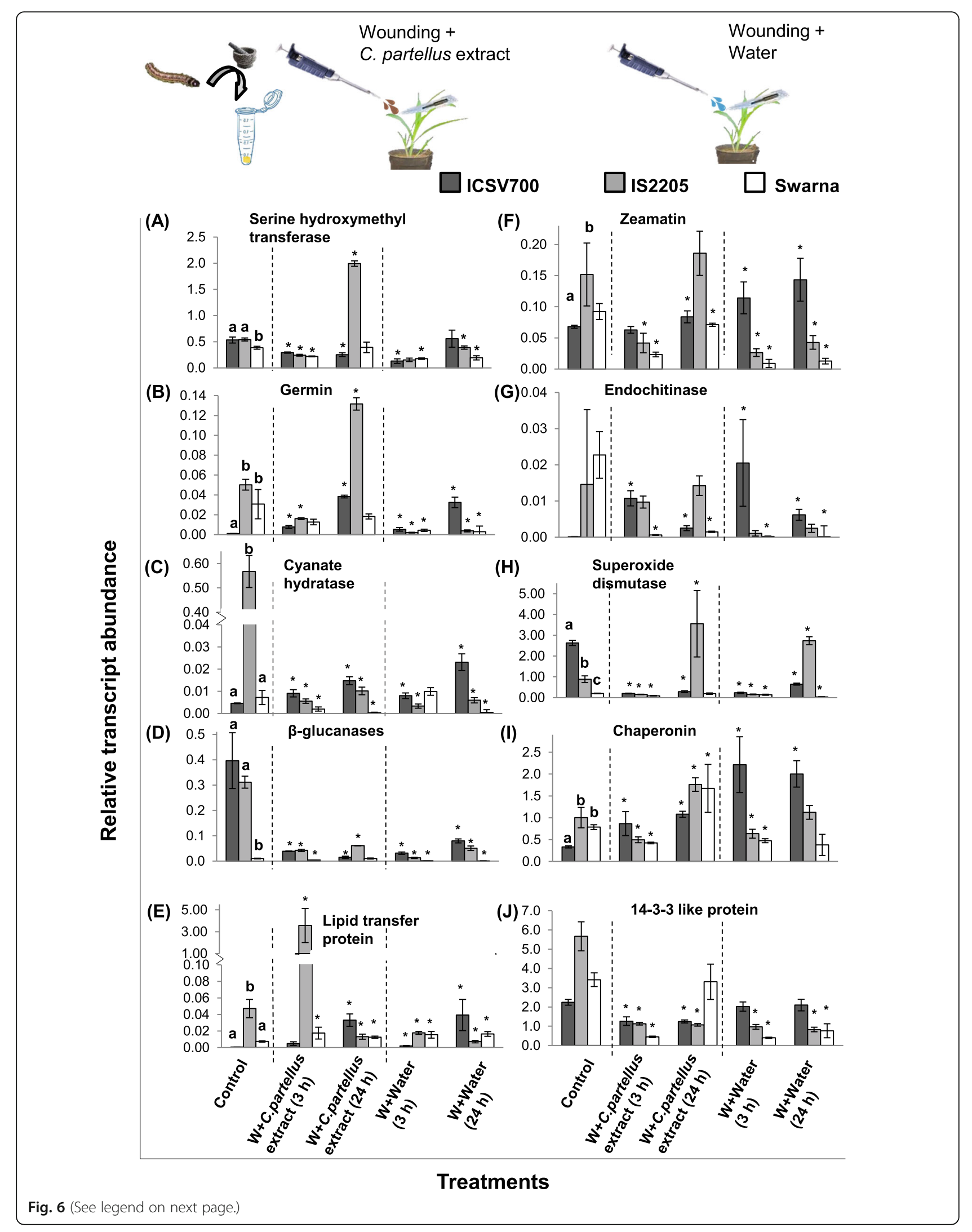


(See figure on previous page.)

Fig. 6 Early ( $3 \& 24$ h) gene expression profiles of selected protein candidates from S. bicolor-C. partellus interaction proteomics study| Relative expression $\left(\Delta \mathrm{Ct}=\mathrm{Ct}_{\mathrm{Gene}}\right.$ of interest $\left.\mathrm{Ct}_{\text {Tubulin }}\right)$ profile of genes corresponding to protein candidates identified from the proteomics study of $\mathrm{S}$. bicolor genotypes ICSV700, IS2205 and Swarna at steady-state and after $3 \mathrm{~h}$ and $24 \mathrm{~h}$ post induced wounding (W + W) and wounding + C. partellus extract $(\mathrm{W}+\mathrm{E})$ treatment, have been represented. The relative gene expression profiles for serine hydroxymethyltransferase $(\mathbf{A})$, germin $(\mathbf{B})$, cyanate hydratase $(\mathbf{C})$, $\beta$ - glucanase $(\mathbf{D})$, lipid transfer protein $(\mathbf{E})$, zeamatin $(\mathbf{F})$, endochitinase $(\mathbf{G})$, superoxide dismutase $(\mathbf{H})$, chaperonin $(\mathbf{I})$, 14-3-3 like protein (J) are shown. Tubulin was used as housekeeping control. The student's t-test followed by Tukey's HSD (Honestly Significant Difference) test was performed on the data to identify significant differences if any at $p<0.05$. $\left({ }^{*} p<0.05\right)$

wheat stem sawfly [54]. 14-3-3 isoforms are differentially regulated by hormonal treatments, biotic and abiotic stress [55]; and in turn signal defense response to stresses in plants. Another protein specifically accumulated in resistant genotypes of S. bicolor was the superoxide dismutase (SOD), a radical quenching enzyme. High SOD activity has been noted in aphid-infested wheat plants [56], upon mite infestation in cassava [57] and has been strongly correlated to enhanced resistance to the invading pest. Differential SOD levels and isoform diversity are found to play a role in maintaining the cytosolic redox state which in turn regulates response to a variety of pathogens [58] and is probably important in mediating defense against Lepidopteran pests as well. Further, our proteomic analysis on insect-resistant S. bicolor indicated abundance of polyphenol oxidases (PPO) upon C. partellus infestation, unlike that in the susceptible genotype Swarna. Apart from its role in defense against pests and pathogens, our data supports the coupregulation/co-expression of PPO with PSII and other photosynthesis proteins, signifying its function in protecting the photosynthetic apparatus and eventually in maintaining plant viability and growth [59]. Both the resistant genotypes at steady state $(B, D)$ were rich in proteins involved in primary metabolic processes, efficient protein synthesis, regulation and nitrogen compound biosynthesis contributing to the insect resistance characters.

At steady-state both of the resistant S. bicolor genotypes were found to have a higher abundance of more than 50 proteins as compared to the susceptible genotype Swarna (Fig. 4B, C; Supplementary Table 2). These proteins were involved in maintaining a strong primary metabolism, efficient generation of energy, proficient cell communication and cell cycle in the resistant genotypes. These were represented by proteins like malate dehydrogenase which performs a key role in plant metabolism, chlorophyll a-b binding protein in photosynthesis, magnesium chelatases to regulate abscisic acid (ABA) signaling [60, 61], Glutathione S-transferases (GST) involved abiotic stress tolerance [62]. An interesting protein namely the F-box associated LRR protein was also detected only in the resistant $S$. bicolor genotypes at steady-state and may be looked upon as an important contributor to defense against insects. Recent studies have highlighted the importance of rice LRR protein as a component of plant exocyst, majorly contributing resistance to the insect pest - brown planthopper (BPH) [63].

At steady-state, ICSV700 was found to have higher levels of S-adenosyl methionine synthase (SAM synthase), subtilisin, pectinesterase, PPO, ascorbate peroxidase. Enhanced plant defense against insect pests has been demonstrated by SAM synthase through its role in polyamine synthesis [64], subtilisin, pectin esterases [65], polyphenol oxidases [66] and ascorbate peroxidase [67] showing them to be interesting candidates for reverse genetic studies and further elucidation of their mechanisms in defense (Fig. 4B and Supplementary Table 2).

\section{Distinctive proteomic features of $S$. bicolor genotypes}

A high number of unique proteins in resistant S. bicolor, even at steady-state, indicated that they may act synergistically to maintain the resistance against pests, thereby, reducing the chances of infestation (Fig. 5; Table 4). Some of the high expressing unique proteins from S. bicolor ICSV700 at steady-state are involved in the development, maintenance of plant architecture, defense and drought tolerance represented by proliferation-associated protein 2G4, FACT complex subunit SPT16, brassinosteroid insensitive-1 like protein [68], arginine decarboxylase and nitrate reductase [69] respectively. While upon infestation by $C$. partellus, $S$. bicolor ICSV700 uniquely expressed several transcription factors and enzymes which were involved in defense against pathogens, indirect defense to herbivorous pests, development of defensive structures, wound healing /cell proliferation and showed high protein remodeling and turnover. Notable amongst them were the ATP synthase CF1 alpha subunit, $\beta$-caryophyllene synthase, and Ankyrin repeats domain-containing protein. $\beta$-Caryophyllene synthase is known to enhance the volatile emission from S. bicolor attracting C. partellus's larval parasitoid, Cotesia sesamiae Cameron (Hymenoptera: Braconidae) [70]. It is exciting to detect it in infested resistant variety ICSV700 and it also explains different strategies taken by the genotypes to deter the pest. When cultivated maize varieties were not able to express $\beta$-Caryophyllene synthase upon $C$. partellus infestation, it rendered them susceptible to insect pests [71, 72]. Ankyrin repeat 
domain-containing proteins are involved in growth, development, protein-protein interactions and have a potential role in plant defense [73].

The other resistant variety IS2205 at steady-state uniquely expressed proteins involved in mediating stress tolerance, conferring antioxidant property and plant resistance represented by peroxidases, thiamine thiazole synthase 1, glutaredoxin and IAA amido synthase GH3, diaminopimelate decarboxylase respectively (Fig. 5; Table 4). While upon C. partellus infestation it uniquely expressed proteins involved in signaling stress tolerance like monogalactosyldiacyl glycerol synthase, zinc finger $\mathrm{CCCH}$ domain-containing protein, thiazole synthase; and proteins involved in direct defense signaling like RPP-13 like and chitinase. Maintaining thylakoid membrane biogenesis and stomata opening for retention of photosynthetic capacities in plants under stress is a prominently noted process in IS2205 S. bicolor genotype mediated by monogalactosyldiacyl glycerol synthase and thiazole synthase $[74,75]$. Further, NBS-LRR family protein RPP-13 is an important contributor to disease, insect herbivore resistance and also abiotic stress tolerance in plants $[63,76]$.

In contrast to the S. bicolor resistant varieties the susceptible variety Swarna at steady-state uniquely expressed proteins involved in development and homeostasis and upon C. partellus infestation proteins for development, stress management/ defense and homeostasis represented by adenylate isopentenyltransferase, sorbitol-6-phosphate dehydrogenase, serine-threonine kinases, BOI related E3 ubiquitin-protein ligase and triacylglycerol lipase SDP1 respectively were expressed (Fig. 5 and Table 4). Serine/threonine kinases are involved in a wide array of processes ranging from signal transduction, disease resistance, developmental regulation to self- versus non-self-recognition [77] and plant defense response signaling against the pathogen [78, 79]. Ubiquitin/proteasome system (UPS) plays an important role in proteome remodeling in plant-virus interactions, defense against pathogens and survival during environmental stress $[80,81]$.

\section{The dynamics of gene expression and protein accumulation lead to differences in the correlation of gene vs proteomics profiles in S. bicolor}

The gene expression profiles of selected genes thought to be involved in insect defense were studied in $S$. bicolor upon wounding and/or insect extract-treatment. The analysis confirmed that $S$. bicolor genotypes responded differently to the insect extract and wounding treatments. The analysis indicated that early gene expression profiles of only some gene candidates correlate with the late proteomic profiles. The differences in proteomic vs gene expression studies in S. bicolor can be attributed to the variation in age of plants used; fieldgrown vs polyhouse grow plants; actual C. partellus infestation vs mimicking of the infestation and prolonged infestation vs early hours after mimicking infestation in the $S$. bicolor genotypes respectively. The differences in the proteomic and mRNA expression patterns are noted in many studies and have been attributed to the existence of gene isoforms [82]; feedback regulatory circuits [83] and can be indicative of varied rates of protein translation or post-translational regulations [84].

\section{Conclusions}

In conclusion, the proteomic analysis of 967 proteins from S. bicolor genotypes at steady-state and upon infestation by $C$. partellus was performed. The different statistical comparisons amongst the genotypes and treatments revealed the proteins which would be important for insect defense in S. bicolor. Due to the intrinsic limitations associated with protein annotations, there is a possibility of missing out on some very interesting proteins which are yet to be functionally annotated. However, the present analysis has revealed several proteins that are probably individually or synergistically used by undomesticated S. bicolor genotypes to strengthen its resistance to insect pests. The differentially expressed proteins in resistant vs susceptible $S$. bicolor genotypes and the uniquely expressed proteins identified, potentially contribute to the build-up of defense against C. partellus using different mechanisms. Further analysis of the protein-protein interactions, pathways and reverse genetic approach would help to identify the different strategies plants may adopt simultaneously to fight against insect pests and to develop agronomically beneficial yet insect-resistant crop plants.

\section{Abbreviations \\ JA: Jasmonic acid; SA: Salicylic acid; ROS: Reactive oxygen species; RBD: Randomized complete block design; GO: Gene ontology}

\section{Supplementary Information}

The online version contains supplementary material available at https://doi. org/10.1186/s12953-021-00173-z.

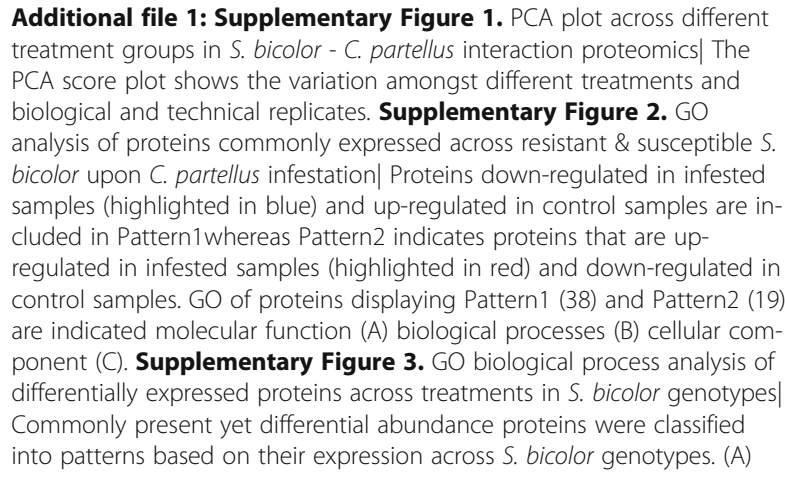


Pattern3 listed proteins (11) generally down-regulated in S. bicolor upon C. partellus infestation, where one of the S. bicolor genotypes displayed a contrasting expression as indicated in the insets (difference in $A / B ; C / D$ or E/F) (B) Pattern4 listed proteins (25) generally up-regulated in S. bicolor upon C. partellus infestation, where one of the S. bicolor genotypes displayed a contrasting expression as indicated in the insets (difference in $\mathrm{A} / \mathrm{B} ; \mathrm{C} / \mathrm{D}$ or $\mathrm{E} / \mathrm{F})$. 'Difference in $\mathrm{A} / \mathrm{B}^{\prime}$ demonstrates a contradictory pattern in ICSV700, similarly 'Difference in C/D' represents in IS2205 and 'Difference in $E / F^{\prime}$ represents in Swarna respectively.

Additional file 2: Supplementary Table 1. Proteins commonly expressed in all treatments yet differentially expressed across S. bicolor genotypes upon C. partellus infestation and at steady state (Pattern 3 and Pattern 4). Supplementary Table 2. List of differentially abundant proteins in S. bicolor infested with pest C. partellus (A, C, E) and in S. bicolor at steady state $(B, D, F)$ treatments. These proteins signify how the resistant genotypes of S. bicolor ICSV700 and IS2205 manifest their resistance to insect pests and the susceptible genotype Swarna cannot. Supplementary Table 3. Gene-specific primers used for the qRT-PCR analysis of selected candidate genes of $\mathrm{S}$. bicolor plants induced by wounding and C. partellus extract. The gene expression analysis focuses on the early response ( $3 \mathrm{~h}$ to $24 \mathrm{~h}$ ) by S. bicolor to the inductions.

Additional file 3. Supplementary Data (excel files) provided with the manuscript. 1. Sample A vs B. 2. Sample C vs D. 3. Sample E vs F. Pairwise comparison of proteins from $C$. partellus induced and steady state from the three genotypes of S. bicolor, ICSV700 (A vs B), IS2205 (C vs D) and Swarna (E vs F). The excels sheets provide a list of up and down regulated proteins which are obtained based on the data analysis performed with PLGS, Waters.

\section{Acknowledgments}

This work was supported by the Young Scientist research grant to VT from the Science and Engineering Research Board, Department of Science and Technology, Government of India, India. Grant Number SB/YS/LS-132/2013. The authors express thanks to Dr. Vandana Mhaske for her valuable suggestions and editing of the manuscript. The funding support from the Departmental Research and Development Program (DRDP), Institute of Bioinformatics and Biotechnology, Savitribai Phule Pune University, Pune is acknowledged.

\section{Conflict of interest}

The authors declare no competing financial or non-financial conflict of interest.

\section{Authors' contributions}

$V T$ conceived, planned, supervised and procured funding for the project; AJ performed the field experiment and AJ, SS performed the laboratory experiments; AJ, SS, VT collected and analyzed the data; AW and HS suggested the plant genotypes be used and provided the field experimentation; AJ carried out the MS experiments and analysis; AK and SS carried out the statistical analysis of the data; SS, AK, AJ and VT prepared the figures and illustrations; VT and SS wrote the manuscript with inputs from the other authors. The authors read and approved the final manuscript.

\section{Authors' information}

SS and AJ contributed equally to this work.

\section{Funding}

This work was supported by the Young Scientist research grant to VT from the Science and Engineering Research Board, Department of Science and Technology, Government of India, India. Grant Number SB/YS/LS-132/2013.

\section{Availability of data and materials}

The data in excel sheets has been attached with the manuscript as supplementary files. Any other data set generated in the study will be made available from the corresponding author on reasonable request.

\section{Declarations}

\section{Ethics approval and consent to participate}

Ethical approval was not needed for this work. All authors and participating institutes willing participated in the study.

\section{Consent for publication}

Not applicable.

\section{Competing interests}

Authors declare no competing interests.

\section{Author details}

${ }^{1}$ Institute of Bioinformatics and Biotechnology (IBB), Savitribai Phule Pune University (SPPU), Ganeshkhind Road, Pune, Maharashtra 411 007, India. ${ }^{2}$ Present Address: Indian Institute of Science, Education \& Research, Dr. Homi Bhaha Road, NCL Colony, Pune, Maharashtra 411008, India. ${ }^{3}$ International Crop Research Institute for the Semi-Arid -Tropics (ICRISAT), Patancheru, Telangana 502324, India. ${ }^{4}$ Present Address: World Vegetable Center, South Asia, ICRISAT campus, Patancheru, Telangana 502324, India. ${ }^{5}$ Present Address: Dr. YSP University of Horticulture and Forestry, Nauni, Solan, HP 173230, India. ${ }^{6}$ Rajiv Gandhi Centre for Biotechnology, Thiruvananthapuram, Kerala 695014, India. 'Department of Statistics, SPPU, Ganeshkhind Road, Pune, Maharashtra 411 007, India.

Received: 14 September 2020 Accepted: 11 March 2021

Published online: 02 April 2021

\section{References}

1. Bantilan MCS, Deb UK, Gowda CLL, Reddy BVS OA and ER. Sorghum genetic enhancement: research process, dissemination and impactsInt. Crop. Res. Inst. Semi-Arid Trop; 2004.

2. Ngara R, Ndimba BK. Model plant systems in salinity and drought stress proteomics studies: a perspective on Arabidopsis and sorghum. Plant Biol. 2014;16(6):1029-32. https://doi.org/10.1111/plb.12247.

3. Labuschagne MT. A review of cereal grain proteomics and its potential for sorghum improvement. J Cereal Sci. 2018;84:151-8. https://doi.org/10.1016/j. jcs.2018.10.010.

4. Harris KM. Bioecology of Chilo species. Insect Sci Appl. 1990;11:467-77.

5. Sharma HC, Taneja SL, Leuschner K, Nwanze KF. Techniques to screen sorghums for resistance insect pests; 1992.

6. Sharma HC, Singh F, Nwanze KF. Plant resistance to insects in sorghum; 1997.

7. Sharma AN, Sharma VK. Studies on the economic injury level in maize, zea mays I. to stem borer, chilo partellus (swinhoe)(pyralidae: Lepidoptera)in India. Trop Pest Manag. 1987:33(1):44-51. https://doi.org/10.1080/ 09670878709371114

8. Chamarthi SK, Sharma HC, Sahrawat KL, Narasu LM, Dhillon MK. Physicochemical mechanisms of resistance to shoot fly, Atherigona soccata in sorghum, Sorghum bicolor. J Appl Entomol. 2011;135(6):446-55. https://doi. org/10.1111/j.1439-0418.2010.01564.x

9. Singh BU, Sharma HC, Rao KV. Mechanisms and genetic diversity for host plant resistance to spotted stem borer, Chilo partellus in sorghum, Sorghum bicolor. J Appl Entomol. 2012;136(5):386-400. https://doi.org/10.1111/j.14390418.2011.01647x

10. Rosenthal JP, Dirzo R. Effects of life history, domestication and agronomic selection on plant defence against insects: evidence from maizes and wild relatives. Evol Ecol. 1997;11(3):337-55. https://doi.org/10.1023/A:101842 0504439.

11. Whitehead SR, Turcotte MM, Poveda K. Domestication impacts on plantherbivore interactions: a meta-analysis. Phil Trans R Soc. 2016;372:1-9.

12. Kamala V, Sivaraj N, Pandravada SR, Rameash K, Sharma HC, Babu BS, et al. Potential of wild relatives in sorghum improvement through molecular approaches; 2016. p. 124-5.

13. Padmaja PG, Aruna C. Advances in sorghum insect pest resistance. In: Breed. Sorghum divers. End uses: Elsevier Ltd; 2018. https://doi.org/10.1016/B978-008-101879-8.00018-8.

14. Dyer LA, Philbin CS, Ochsenrider KM, Richards LA, Massad TJ, Smilanich AM, et al. Modern approaches to study plant-insect interactions in chemical ecology. Nat Rev Chem. 2018;2(6):50-64. https://doi.org/10.1038/s41570-01 8-0009-7. 
15. Tan BC, Lim YS, Lau SE. Proteomics in commercial crops: An overview. J Proteomics. 2017;169:176-88. https://doi.org/10.1016/j.jprot.2017.05.018.

16. Walley JW, Shen Z, Sartor R, Wu KJ, Osborn J, Smith LG, et al. Reconstruction of protein networks from an atlas of maize seed proteotypes. Proc Natl Acad Sci U S A. 2013;110(49):E4808-E4817. https://www.pnas.org/content/11 0/49/E4808.full

17. Ngara R, Ramulifho E, Movahedi M, Shargie NG, Brown AP, Chivasa S. Identifying differentially expressed proteins in sorghum cell cultures exposed to osmotic stress. Sci Rep. 2018;8:1-12.

18. Cremer JE, Liu L, Bean SR, Ohm JB, Tilley M, Wilson JD, et al. Impacts of kafirin allelic diversity, starch content, and protein digestibility on ethanol conversion efficiency in grain sorghum. Cereal Chem. 2014;91(3):218-27. https://doi.org/10.1094/CCHEM-04-13-0068-R.

19. Benmoussa M, Chandrashekar A, Ejeta G, Hamaker BR. Cellular response to the high protein digestibility/high-lysine (hdhl) sorghum mutation. Plant Sci. 2015;241:70-7. https://doi.org/10.1016/j.plantsci.2015.08.025.

20. Roy SJ, Negrão S, Tester M. Salt resistant crop plants. Curr Opin Biotechnol. 2014;26:115-24. https://doi.org/10.1016/j.copbio.2013.12.004.

21. Roy SK, Cho SW, Kwon SJ, Kamal AHM, Kim SW, Oh MW, et al. Morphophysiological and proteome level responses to cadmium stress in sorghum. PLoS One. 2016;11:1-27.

22. Zhou D, Yang Y, Zhang J, Jiang F, Craft E, Thannhauser TW, et al. Quantitative ITRAQ proteomics revealed possible roles for antioxidant proteins in sorghum aluminum tolerance. Front Plant Sci. 2017;7:1-14.

23. Oliveira FDB, Miranda RDS, Araújo S, Coelho DG, Duarte M, Lobo P, et al. New insights into molecular targets of salt tolerance in sorghum leaves elicited by ammonium nutrition. Plant Physiol BiochemElsevier Masson SAS. 2020. https://doi.org/10.1016/j.plaphy.2020.06.051.

24. Zhu L, Wang D, Sun J, Mu Y, Pu W, Ma B, et al. Phenotypic and proteomic characteristics of sorghum (Sorghum bicolor) albino lethal mutant sbe6-a1. Plant Physiol Biochem. 2019;139:400-10. https://doi.org/10.1016/j.plaphy.201 9.04.001.

25. Goche T, Shargie NG, Cummins I, Brown AP, Chivasa S, Ngara R. Comparative physiological and root proteome analyses of two sorghum varieties responding to water limitation. Sci Rep. 2020;10:1-18. https://doi. org/10.1038/s41598-020-68735-3.

26. Olalde-Portugal V, Cabrera-Ponce JL, Gastelum-Arellanez A, Guerrero-Rangel A, Winkler $\mathrm{R}$, Valdés-Rodríguez $\mathrm{S}$. Proteomic analysis and interactions network in leaves of mycorrhizal and nonmycorrhizal sorghum plants under water deficit. PeerJ. 2020;2020:1-29.

27. Zhu R, Zhao Z, Wang J, Bai B, Wu A, Yan L, et al. A simple sample pretreatment method for multi-mycotoxin determination in eggs by liquid chromatography tandem mass spectrometry. J Chromatogr A. 2015;1417:17. https://doi.org/10.1016/j.chroma.2015.09.028

28. Padmaja PG. Insect Pest resistance in sorghum. In: Biot. Stress resist. Millets: Elsevier Inc:; 2016. https://doi.org/10.1016/B978-0-12-804549-7.00004-4.

29. Muturi PW, Mgonja M, Rubaihayo P. Gene action conditioning resistance traits to spotted stem borer, Chilo partellus, in grain sorghum. Int J Trop Insect Sci. 2019;39(2):147-55. https://doi.org/10.1007/s42690-019-00020-x.

30. International Board for Plant Genetic Resources. International crops research Institute for the Semi-arid Tropics. Descriptors for sorghum: Sorghum bicolor (L.) Moench = Descripteurs du sorgho : Sorghum bicolor (L.) Moench; 1993.

31. Howe GA, Jander G. Plant immunity to insect herbivores. Annu Rev Plant Biol. 2008:59(1):41-66. https://doi.org/10.1146/annurev.arplant.59.032607.092825.

32. Kessler A, Baldwin IT. Plant responses to insect herbivory: the emerging molecular analysis. Annu Rev Plant Biol. 2002;53(1):299-328. https://doi.org/1 0.1146/annurev.arplant.53.100301.135207.

33. Wu J, Baldwin IT. New insights into plant responses to the attack from insect herbivores. Annu Rev Genet. 2010;44(1):1-24. https://doi.org/10.114 6/annurev-genet-102209-163500

34. Sharan AA, Nikam AN, Jaleel A, Tamhane VA, Rao SP. Method for labelfree quantitative proteomics for Sorghum bicolor L. Moench Trop Plant Biol Trop Plant Biol. 2018;11(1-2):78-91. https://doi.org/10.1007/s12042018-9202-6.

35. Bradford MM. A dye binding assay for protein. Anal Biochem. 1976;72:24854. https://doi.org/10.1006/abio.1976.9999.

36. Howe EA, Sinha R, Schlauch D, Quackenbush J. RNA-Seq analysis in MeV. Bioinformatics. 2011;27(22):3209-10. https://doi.org/10.1093/bioinformatics/ btr490.

37. Bateman A. UniProt: a worldwide hub of protein knowledge. Nucleic Acids Res. 2019;47:D506-15.
38. Mi H, Muruganujan A, Huang X, Ebert D, Mills C, Guo X, et al. Protoco update for large-scale genome and gene function analysis with the PANT HER classification system (v.14.0). Nat Protoc. 2019;14(3):703-21. https://doi. org/10.1038/s41596-019-0128-8.

39. Raudvere U, Kolberg L, Kuzmin I, Arak T, Adler P, Peterson H, et al. G:profiler: a web server for functional enrichment analysis and conversions of gene lists (2019 update). Nucleic Acids Res. 2019;47(W1):W191-8. https://doi.org/1 $0.1093 /$ nar/gkz369.

40. Guo DD, Guo QH, Gao YGM. Expression of ATP synthase CF1 alpha subunit gene (CTL-spn) as screened by the CDNA-SRAP approach is correlated with spininess in Carthamus tinctorius L. Acta Pharm Sin. 2015;50:1052-9 https:// www.ncbi.nlm.nih.gov/pubmed/26669008.

41. Ghatak A, Chaturvedi P, Weckwerth W. Cereal crop Proteomics : systemic analysis of crop drought stress responses towards marker-assisted selection breeding; 2017. p. 8.

42. Chen YH, Gols R, Benrey B. Crop domestication and its impact on naturally selected trophic interactions. Annu Rev Entomol. 2015;60(1):35-58. https:// doi.org/10.1146/annurev-ento-010814-020601.

43. Gaillard MDP, Glauser G, Robert CAM, Turlings TCJ. Fine-tuning the 'plant domestication-reduced defense' hypothesis: specialist vs generalist herbivores. New Phytol. 2018;217(1):355-66. https://doi.org/10.1111/nph.14 757.

44. Martinez-Medina A, Flors V, Heil M, Mauch-Mani B, Pieterse CMJ, Pozo MJ, et al. Recognizing plant defense priming. Trends Plant Sci. 2016;21(10):81822. https://doi.org/10.1016/j.tplants.2016.07.009.

45. Torp M, Lehrman A, Stenberg JA, Julkunen-Tiitto R, Björkman C. Performance of an herbivorous leaf beetle (Phratora vulgatissima) on Salix F2 hybrids: the importance of Phenolics. J Chem Ecol. 2013;39(4):516-24. https://doi.org/10.1007/s10886-013-0266-3.

46. Alseekh S, Perez de Souza L, Benina M, Fernie AR. The style and substance of plant flavonoid decoration; towards defining both structure and function. Phytochemistry. 2020;174:112347. https://doi.org/10.1016/j.phytochem.2020.112347.

47. Ranty B, Aldon D, Galaud J-P. Plant Calmodulins and Calmodulin-related proteins. Plant Signal Behav. 2011;1:96-104.

48. Trusov Y, Botella JR. Plant G-proteins come of age: breaking the bond with animal models. Front Chem. 2016;4:1-9.

49. Ali S, Ganai BA, Kamili AN, Bhat AA, Mir ZA, Bhat JA, et al. Pathogenesisrelated proteins and peptides as promising tools for engineering plants with multiple stress tolerance. Microbiol Res. 2018;212-213:29-37. https:// doi.org/10.1016/j.micres.2018.04.008.

50. Rasoolizadeh A, Munger A, Goulet MC, Sainsbury F, Cloutier C, Michaud D. Functional proteomics-aided selection of protease inhibitors for herbivore insect control. Sci Rep Nature. 2016;6:1-10.

51. Kumar S, Kanakachari M, Gurusamy D, Kumar K, Narayanasamy P, Kethireddy Venkata P, et al. Genome-wide transcriptomic and proteomic analyses of bollworm-infested developing cotton bolls revealed the genes and pathways involved in the insect pest defence mechanism. Plant Biotechnol J. 2016;14(6):1438-55. https://doi.org/10.1111/pbi.12508.

52. Moreno Jl, Martín R, Castresana C. Arabidopsis SHMT1, a serine hydroxymethyltransferase that functions in the photorespiratory pathway influences resistance to biotic and abiotic stress. Plant J. 2005;41(3):451-63. https://doi.org/10.1111/j.1365-313X.2004.02311.x.

53. González-Bosch C. Priming plant resistance by activation of redox-sensitive genes. Free Radic Biol Med. 2018;122:171-80. https://doi.org/10.1016/jfreera dbiomed.2017.12.028.

54. Lavergne FD, Broeckling CD, Brown KJ, Cockrell DM, Haley SD, Peairs FB, et al. Differential stem proteomics and metabolomics profiles for four wheat cultivars in response to the insect Pest wheat stem sawfly. J Proteome Res. 2020;19(3):1037-51. https://doi.org/10.1021/acs.jproteome.9b00561.

55. Chen F, Li Q, Sun L, He Z. The rice 14-3-3 gene family and its involvement in responses to biotic and abiotic stress. DNA Res. 2006;13(2):53-63. https:// doi.org/10.1093/dnares/dsl001.

56. Kaur H, Salh PK, Singh B. Role of defense enzymes and phenolics in resistance of wheat crop (Triticum aestivum L.) towards aphid complex. J Plant Interact. 2017;12:304-11.

57. Lu F, Liang X, Lu H, Li Q, Chen Q, Zhang P, et al. Overproduction of superoxide dismutase and catalase confers cassava resistance to Tetranychus cinnabarinus. Sci Rep. 2017;7(1):1-13. https://doi.org/10.1038/srep40179.

58. Lightfoot DJ, Mcgrann GRD, Able AJ. The role of a cytosolic superoxide dismutase in barley-pathogen interactions. Mol Plant Pathol. 2017;18(3): 323-35. https://doi.org/10.1111/mpp.12399. 
59. Boeckx T, Winters A, Webb KJ, Kingston-Smith AH. Detection of potential chloroplastic substrates for polyphenol oxidase suggests a role in undamaged leaves. Front Plant Sci. 2017;8. https://doi.org/10.3389/fpls.2017. 00237.

60. Pietrzykowska M, Suorsa M, Semchonok DA, Tikkanen M, Boekema EJ, Aro E$M$, et al. The light-harvesting chlorophyll a/b binding proteins Lhcb1 and Lhcb2 play complementary roles during state transitions in Arabidopsis. Plant Cell. 2014:26(9):3646-60. https://doi.org/10.1105/tpc.114.127373.

61. Du SY, Zhang XF, Lu Z, Xin Q, Wu Z, Jiang T, et al. Roles of the different components of magnesium chelatase in abscisic acid signal transduction. Plant Mol Biol. 2012;80(4-5):519-37. https://doi.org/10.1007/s11103-0129965-3.

62. Kumar S, Trivedi PK. Glutathione S-transferases: role in combating abiotic stresses including arsenic detoxification in plants. Front Plant Sci. 2018;9:1-9.

63. Guo J, Xu C, Wu D, Zhao Y, Qiu Y, Wang X, et al. Bph6 encodes an exocystlocalized protein and confers broad resistance to planthoppers in rice. Nat Genet. 2018;50(2):297-306. https://doi.org/10.1038/s41588-018-0039-6.

64. Alcázar R, Altabella T, Marco F, Bortolotti C, Reymond M, Koncz C, et al. Polyamines: molecules with regulatory functions in plant abiotic stress tolerance. Planta. 2010;231(6):1237-49. https://doi.org/10.1007/s00425-01 0-1130-0.

65. Silva-Sanzana C, Celiz-Balboa J, Garzo E, Marcus SE, Parra-Rojas JP, Rojas B, et al. Pectin Methylesterases modulate plant Homogalacturonan status in defenses against the aphid Myzus persicae. Plant Cell. 2019;31(8):1913-29. https://doi.org/10.1105/tpc.19.00136

66. Taranto F, Pasqualone A, Mangini G, Tripodi P, Miazzi MM, Pavan S, et al. Polyphenol oxidases in crops: biochemical, physiological and genetic aspects. Int J Mol Sci. 2017;18(2). https://doi.org/10.3390/ijms18020377.

67. Mai VC, Tran NT, Nguyen DS. The involvement of peroxidases in soybean seedlings' defense against infestation of cowpea aphid. Arthropod Plant Interact. 2016;10(4):283-92. https://doi.org/10.1007/s11829-016-9424-1.

68. Nakashita H, Yasuda M, Nitta T, Asami T, Fujioka S, Arai Y, et al. Brassinosteroid functions in a broad range of disease resistance in tobacco and rice. Plant J. 2003;33(5):887-98. https://doi.org/10.1046/j.1365-313X.2003. 01675.x.

69. Kaur R, Gupta AK, Taggar GK. Nitrate reductase and nitrite as additional components of defense system in pigeonpea (Cajanus cajan L.) against Helicoverpa armigera herbivory. Pestic Biochem Physiol. 2014;115:39-47. https://doi.org/10.1016/j.pestbp.2014.08.005.

70. Mutyambai DM, Bruce TJA, Midega CAO, Woodcock CM, Caulfield JC, Van Den Berg J, et al. Responses of parasitoids to volatiles induced by Chilo partellus Oviposition on Teosinte, a wild ancestor of maize. J Chem Ecol. 2015;41(4):323-9. https://doi.org/10.1007/s10886-015-0570-1.

71. Köllner TG, Held M, Lenk C, Hiltpold I, Turlings TCJ, Gershenzon J, et al. A maize (E)- $\beta$-caryophyllene synthase implicated in indirect defense responses against herbivores is not expressed in most American maize varieties. Plant Cell. 2008;20(2):482-94. https://doi.org/10.1105/tpc.107.051672.

72. Cheng $A X$, Xiang CY, Li JX, Yang CQ, Hu WL, Wang LJ, et al. The rice (E)- $\beta$ caryophyllene synthase (OsTPS3) accounts for the major inducible volatile sesquiterpenes. Phytochemistry. 2007;68(12):1632-41. https://doi.org/10.101 6/j.phytochem.2007.04.008.

73. Vo KTX, Kim CY, Chandran AKN, Jung KH, An G, Jeon JS. Molecular insights into the function of ankyrin proteins in plants. J Plant Biol. 2015;58(5):27184. https://doi.org/10.1007/s12374-015-0228-0.

74. Rocha J, Nitenberg M, Girard-Egrot A, Jouhet J, Maréchal E, Block MA, et al. Do galactolipid synthases play a key role in the biogenesis of chloroplast membranes of higher plants? Front Plant Sci. 2018;9:1-7.

75. Li CL, Wang M, Wu XM, Chen DH, Lv HJ, Shen JL, et al. THI1, a thiamine thiazole synthase, interacts with Ca2+-dependent protein kinase CPK33 and modulates the s-type anion channels and stomatal closure in arabidopsis. Plant Physiol. 2016;170(2):1090-104. https://doi.org/10.1104/pp.15.01649.

76. Xu Y, Liu F, Zhu S, Li X. The maize NBS-LRR gene ZmNBS25 enhances disease resistance in rice and arabidopsis. Front Plant Sci. 2018;9:1-13.

77. Goring DR, Walker JC. Self-rejection - a new kinase connection. Science (80). 2004;303:1474-5

78. Martin GB, Brommonschenkel SH, Chunwongse J, Ganal MW, Spivey R, WU $T$, et al. Map-based cloning of a protein kinase gene conferring disease resistance in tomato. Published by: American Association for the Advancement of Science Stable URL : http://www.jstor.org/stable/2882432. Adv Sci. 2008:262:1432-6.
79. Song W, Wang G, Chen L, Kim H, Pi L, Hoisten T, et al. A Receptor KinaseLike Protein Encoded. Science. 1995;270:1804-6. Available from: https:// science.sciencemag.org/content/270/5243/1804

80. Zhou H, Zhao J, Cai J, Patil SB. UBIQUITIN-SPECIFIC PROTEASES function in plant development and stress responses. Plant Mol Biol. 2017;94(6):565-76 https://doi.org/10.1007/s11103-017-0633-5.

81. Devoto A, Muskett PR, Shirasu K. Role of ubiquitination in the regulation of plant defence against pathogens. Curr Opin Plant Biol. 2003;6(4):307-11. https://doi.org/10.1016/\$1369-5266(03)00060-8.

82. Giri AP, Wünsche H, Mitra S, Zavala JA, Muck A, Svatoš A, et al. Molecular interactions between the specialist herbivore Manduca sexta (Lepidoptera, Sphingidae) and its natural host Nicotiana attenuata. VII. Changes in the plant's proteome. Plant Physiol. 2006;142(4):1621-41. https://doi.org/10.11 04/pp.106.088781.

83. Bae MS, Cho EJ, Choi EY, Park OK. Analysis of the Arabidopsis nuclear proteome and its response to cold stress. Plant J. 2003;36(5):652-63. https:// doi.org/10.1046/j.1365-313X.2003.01907.X.

84. Baginsky S, Hennig L, Zimmermann P, Gruissem W. Gene expression analysis, proteomics, and network discovery. Plant Physiol. 2010;152(2):40210. https://doi.org/10.1104/pp.109.150433.

\section{Publisher's Note}

Springer Nature remains neutral with regard to jurisdictional claims in published maps and institutional affiliations.
Ready to submit your research? Choose BMC and benefit from:

- fast, convenient online submission

- thorough peer review by experienced researchers in your field

- rapid publication on acceptance

- support for research data, including large and complex data types

- gold Open Access which fosters wider collaboration and increased citations

- maximum visibility for your research: over $100 \mathrm{M}$ website views per year

At BMC, research is always in progress.

Learn more biomedcentral.com/submissions 